\title{
RADICALIZANDO O IMAGINÁRIO: \\ IMPACTOS DAS TRANSFORMAÇÕES DO TRABALHO NAS \\ CONSTRUÇÕES IMAGÈTICAS DE SI DE DOMÈSTICAS BRASILEIRAS
}

Luísa Maria Silva Dantas ${ }^{1}$

\section{Introdução}

Este artigo resulta de uma pesquisa que se propôs a estudar o trabalho doméstico remunerado e/ou realizado na casa de terceiros como um objeto temporal. Por meio de uma etnografia da duração (Eckert e Rocha, 2013), pautada no tempo plural e lacunar, junto à imaginação criativa, em que foram priorizadas as narrativas biográficas e trajetórias sociais de trabalhadoras domésticas, mas também imagens relativas ao trabalho advindas de outros suportes como fotografias, vídeos e reportagens que constituem o jogo de memórias das entrevistadas e da própria pesquisadora.

Durante o processo de proposição, efetivação e finalização da pesquisa (2012 a 2016), ocorreram mudanças impactantes no que diz respeito a regulamentação do trabalho doméstico no Brasil, mas também no quadro mais global a partir da Convenção 189 e da Recomendação 201 da Organização Internacional do Trabalho - OIT (2011). Em 2012 foi aprovada a Proposta de Emenda Constitucional 66, mas conhecida como a "PEC das Domésticas", seguida da Emenda Constitucional 72/2013, até a Lei Complementar 150/2015. Estes dispositivos visam equiparar os direitos das domésticas com os demais trabalhadores urbanos ${ }^{2}$, além de garantir um trabalho decente para a categoria, incluindo estabilidade, segurança e organização sindical. Além de transformações nos empregos, as novas regulamentações parecem estar causando

\footnotetext{
${ }^{1}$ Universidade Federal do Pará, Brasil. Email: luisadantas1@gmail.com ORCID id: https://orcid.org/0000-0003-0267-2778

${ }^{2}$ Resumidamente a nova Lei insistiu em direitos já sancionados, como a obrigatoriedade do registro da carteira de trabalho, com o piso de um salário mínimo (atualmente 1.039 reais), agora somado de $20 \%$, relativos ao pagamento da Previdência Social (8\%), do Fundo de Garantia por Tempo de Serviço (8\%), o pagamento de um Fundo para eventuais rescisões de contrato $(3,2 \%)$ e acidentes de trabalho $(0,8 \%)$; esses encargos estão concentrados em uma página do Governo denominada eSocial. Também regulamentou a jornada de trabalho ( $8 \mathrm{~h} /$ dia e $44 \mathrm{~h} / \mathrm{semana})$, com até $2 \mathrm{~h}$ de intervalo para o almoço, além do pagamento de horas extras e adicional noturno. As férias de 30 dias com adicional de $1 / 3$ do salário, o décimo terceiro salário, o gozo de feriados e o descanso de um dia na semana, preferencialmente aos domingos, já estavam em voga.
} 


\section{Radicalizando o Imaginário: Impactos das transformações do trabalho...}

impactos no modo como as domésticas estão se subjetivando, imaginando, criando e selecionando imagens a respeito de si.

$\mathrm{O}$ artigo inicia com a discussão dos conceitos que fundamentam a análise empreendida e seus principais autores; ou seja, a realização de uma etnografia da duração que coloca o trabalho doméstico remunerado como um fenômeno temporal, que dura por meio da dialética temporal, da imaginação criadora e do "tempo do mundo". Com uma abordagem antropológica, a etnografia interpela suas interlocutoras pelas suas narrativas biográficas, trajetórias sociais, além da pesquisa em diversos suportes imagéticos que constroem representações e discursos a respeito do trabalho doméstico remunerado.

Posteriormente, apresentaremos imagens, que podem ser textuais, na forma de reportagens, trabalhos científicos e literários; mas também fotográficas e videográficas, para analisar como o trabalho doméstico remunerado tem sido construído historicamente em múltiplos suportes, pautado por elementos de caracterização como a vassoura e o uniforme. Também, na contemporaneidade, sob o impacto das novas regulamentações, com argumentos e representações favoráveis e contrárias às transformações, que estão presentes nas reportagens e em filmes que além de apresentarem diferentes configurações, também refletem criticamente as desigualdades, ambiguidades e precariedades vividas neste trabalho.

Finalizaremos com as imagens produzidas e selecionadas pelas próprias interlocutoras, trabalhadoras domésticas, que vão de encontro àquelas naturalizadas no imaginário social, posto que priorizam imagens de lazer, das suas casas próprias, familiares e das atividades sindicais, por exemplo. Isto para refletirmos sobre os impactos das transformações no emprego e no trabalho que podem estar alterando suas construções de si e elevando sua autoestima.

Etnografia da duração - Narrativas, Imagens e os Jogos de Memória

O conceito de etnografia da duração foi elaborado pelas antropólogas Eckert e Rocha (2013) visando estudar o caráter temporal da experiência humana presente no mundo contemporâneo, e suas repercussões nas práticas e saberes dos indivíduos em suas relações com a cidade (: 13).

Essa experiência temporal se manifesta nos jogos de memória dos habitantes produzindo uma rítmica de tempos superpostos produzidos por identidades narrativas 
com o intuito de perdurarem, assim como, as metrópoles duram; já que "cada acontecimento investigado na cidade é condição do ato de interpretação da cidade" $(: 13)$.

Assim como Velho (1981) constrói uma figura teórica para estudar segmentos de camadas médias no Brasil, mais especificamente na cidade do Rio de Janeiro, as antropólogas também elaboram uma releitura de vários estudiosos para estudar a duração das metrópoles brasileiras, desta vez, no âmbito de Porto Alegre.

A etnografia da duração é aplicada a uma abordagem antropológica de pesquisa e se constitui prioritariamente pelo conceito de dialética temporal de Gaston Bachelard (1989) e da imaginação criadora de Gilbert Durand (1980), ambos franceses. Isto quer dizer que focando no estudo do caráter temporal da experiência urbana e colocando a própria cidade como objeto temporal, as autoras utilizam uma concepção de tempo plural, lacunar e descontínuo, que se torna social a partir das narrativas elaboradas pelos jogos da memória.

A memória, estudada por Henri Bergson (1896), em forma de "imagem-hábito" (repetição) ou "imagem-lembrança" (provocada por uma situação do cotidiano) é constituída por um "eu transcendental” que resguarda suas imagens fora do tempo, independentes do mundo externo. Já para Maurice Halbwachs (1925) a memória é construída pelo presente a partir da negociação de diferentes pertenças, portanto com o "eu empírico", que depende de outros para se constituir enquanto sujeito do e no mundo, portanto tem um caráter coletivo.

Fundamentadas por Bachelard, as autoras propõem a existência da memória coletiva, mas que é composta por múltiplos jogos de memória em que cada narrativa ordena tempos vividos e pensados, a partir de diferentes ritmos, para dar sentido às distintas trajetórias e identidades, posto que lembramos por meio de imagens.

Juntamente à dialética temporal, Eckert e Rocha utilizam a "função fantástica", imaginativa ou fabulatória da memória e, portanto, da narrativa, em que os "territórios da vida urbana (são) como lugares da imaginação de seus habitantes" (Durand, 1979b, 1980).

As identidades narrativas (Ricoeur, 1991) são construídas a partir da relação com os outros, provocando a reflexão do sujeito, que a partir de uma situação social específica se reconstrói, saindo da estabilidade da identidade-idem, para se transformar em identidade-ipse, "pois é por intermédio da identidade narrativa que se tem acesso ao 
sujeito que age, com qualificação ética de ser reflexivo, mediante a experiência do tempo" (Eckert e Rocha, 2013:40).

Para realizarmos uma etnografia da duração as autoras nos sugerem aplicar o método de convergência (Durand, 1980) em que o antropólogo deve imergir nos jogos de memória dos interlocutores da pesquisa, trabalhar com a imaginação criadora presente nas narrativas dos atores, mas também na construção do seu próprio texto; além de produzir e gerar coleções etnográficas ${ }^{3}$ que “consteladas em núcleos organizadores de sentido, ajudam a inferir um conhecimento acerca do fenômeno da duração que ali se apresenta" (: 63).

As imagens serão estudadas através das formas narrativas que adotam para o viver a cidade, mas neste caso, sobretudo, através dos territórios da vida estreitamente vinculados ao mundo do trabalho doméstico.

Ao trabalhar com coleções etnográficas de imagens presentes e passadas, estamos operando com uma convergência de imagens das quais a imaginação criadora do antropólogo participa intensamente em seu processo de produção de imagens como forma de narrar a cidade, dando a ela um continuum de consciência de si e a todos os outros nela representados" (Eckert e Rocha, 2013:60).

No caso desta pesquisa, a cidade se coloca como contexto, mas também como agente das práticas cotidianas das trabalhadoras domésticas, contudo nossa proposta é de também colocar o trabalho doméstico remunerado - TDR como objeto temporal, que dura pela sobreposição do tempo do mundo, das práticas e dos jogos da memória das personagens. Imbricado nos contextos urbanos, esta profissão se apresenta sem muita coesão identitária, ainda que os sindicatos trabalhem nesse sentido, devido às características de suas configurações, mas também por outras adesões serem, ao que parece, prioritárias nas escolhas das trabalhadoras, como a afetividade com os amigos ou parentes ou outras pertenças.

A aplicação do método de convergência em conjunto com a formação de coleções etnográficas visa orientar a interpretação da dialética temporal que subjaz o fenômeno do trabalho doméstico remunerado nas cidades. Nesse sentido, também trabalharemos com as imagens produzidas em campo ou do acervo de domésticas, que são avaliações

\footnotetext{
${ }^{3}$ Este trabalho é desenvolvido no Banco de Imagens e Efeitos Visuais - Biev, que estuda as formas singulares e plurais de construção de tempos sociais vividos na cidade, a partir do estudo de memórias, identidades sociais, práticas e saberes de indivíduos e grupos diversos, responsáveis pelo agenciamento cotidiano dos dramas da vida urbana (Eckert e Rocha, 2013: 11).
} 
subjetivas das formas de interação, das trajetórias sociais e projetos dos sujeitos, com a reflexão sobre o si mesmo.

Desse modo, para que possamos compreender a situação presente das trabalhadoras estudadas, devemos conceber os seus tempos sociais como descontínuos, em que as narrativas imaginativas são construídas para dar sentido às rupturas temporais.

A etnografia da duração é aplicada a contextos citadinos, em que as vivências e avaliações dos personagens se confundem com as próprias imagens e experiências do antropólogo em contextos urbanos. O que se propõe aqui é que além da cidade, o trabalho doméstico também seja analisado por processo semelhante, ou seja, que as imagens construídas nas narrativas e nos jogos de memória das trabalhadoras estejam em diálogo com as imagens da memória coletiva em relação ao trabalho doméstico e da própria antropóloga. A partir desse diálogo plural, assim como a cidade, poderemos interpretar o trabalho doméstico como um fenômeno temporal, que dura e se dinamiza na sobreposição de camadas temporais.

Nossa narrativa, para além da imagem escrita preponderante, também trabalhará com imagens em outros suportes, como análises de filmes e das fotografias disseminadas por veículos de comunicação, mas também produzidas durante o trabalho de campo e que foram fundamentais para que a pesquisadora realizasse uma avaliação de seu trabalho e na maneira que suas interpretações foram influenciadas.

[...] a pesquisa com imagens propicia aos grupos sociais estudados compartilhar das experiências de construção de imagens de si, alcançando, assim, a produção antropológica uma eficácia simbólica na construção de memórias coletivas em comparação com a cultura da escrita que orienta os meios acadêmicos" (Eckert e Rocha, 2013:10).

Apesar da etnografia da duração enfatizar a dialética temporal e a imaginação criadora como propulsoras da duração da cidade e/ou do trabalho doméstico no nosso caso, o tempo contínuo, linear, ou "tempo do mundo" (Ricouer, 1994) também é fundamental para colocarmos em evidencia as transformações dos estilos de vida decorrentes da industrialização, urbanização e globalização nas sociedades complexas, onde coexistem diferentes configurações de valores, que incidem nas formas de organização do trabalho, inclusive com mudanças jurídicas que visam a equiparação de direitos com os demais trabalhadores urbanos. Mas esses próprios eventos e mudanças 
Radicalizando o Imaginário: Impactos das transformações do trabalho... do "tempo do mundo" são incorporados nas narrativas das trabalhadoras domésticas, quando no presente, se reinventam e reconstroem-se em suas narrativas.

Imagens do e no Trabalho Doméstico Remunerado elou Realizado na Casa de Terceiros

Amplamente representada nos romances literários amazônicos ${ }^{4}$, como também nacionais ${ }^{5}$ e internacionais ${ }^{6}$, a personagem da mulher, comumente em situação de desigualdade com os membros da unidade doméstica, desempenhando as atividades domésticas e de cuidados da casa e, frequentemente, se referindo aos donos da casa como padrinhos é bastante familiar nas artes e também no cotidiano das famílias brasileiras, ainda que atualmente em menor número; em qualquer situação que nos remetamos a ela, é facilmente identificada por todos à volta, que se não convivem com alguma, já conheceram ou tem conhecimento de alguém que viva em tal configuração.

Os trabalhos desenvolvidos pelas ciências sociais sobre o trabalho doméstico remunerado parecem surgir na década de 1970 em conjunto às críticas e construção de um pensamento feminista. A coletânea de Chaney e Castro ([1989]1993) Muchacha, Cachifa, Empleada, Empregadinha, serviente y... Más nada - Trabajadoras del hogar en América Latina y el Caribe, apresenta um primeiro conjunto de trabalhados que contemplam o Brasil e vários países latinos, em que o trabalho doméstico remunerado é descrito como el trabajo de la cuarta parte, porque aproximadamente 1 em cada 4 mulheres em todos os países da América Latina era doméstica e este trabalho era uma das ocupações com mais exploração e desigualdade de gênero, raça e classe, além disso, em todos os países o trabalho era desempenhado em mais de $90 \%$ por mulheres.

Neste tópico discorreremos sobre a repercussão das novas medidas em favor das trabalhadoras domésticas do Brasil, que vão desde a PEC 66/2012, passado pela Lei Complementar 150/2015, até os dias atuais, em que a configuração do trabalho vem

\footnotetext{
${ }^{4}$ Belém do Grão-Pará (Dalcídio Jurandir, 1960); Barracão (Sultana Rosenblatt, 1963); Dois Irmãos (Miltom Hatoum, 2006); Uma casa chamada 14 (Maria Cecília, 2003), como exemplos.

${ }^{5}$ Casa Velha (Machado de Assis, 2004[1885];

${ }^{6}$ O Primo Basílio (Eça de Queiroz, [1878]1980); A Distância entre Nós (Thrity Umrigar, 2006);
} 
passando por transformações, no que diz respeito à adequação às novas regras, mas também aos significados atribuídos ao trabalho, tanto por quem o desempenha, como por aqueles que o demandam.

Nesse sentido, consideramos pertinente analisar o tom das reportagens e as imagens que são construídas nos textos, mas também nas fotografias utilizadas para discutir sobre as mudanças nas leis e os impactos para os segmentos interessados. As reportagens podem ser classificadas em duas vertentes, aquelas em que a ênfase é dada ao protagonismo das trabalhadoras, à ampliação dos direitos e às imagens de mulheres realizando afazeres domésticos, predominantemente manuais, em que a raça/cor se coloca como um componente muito relevante, devido à maioria das domésticas serem negras, mas não problematizado, ainda que a PEC seja, muitas vezes, denominada de "lei Áurea moderna"7 , fazendo alusão à abolição da escravatura.

Também reportagens chamando atenção para a diminuição do número de trabalhadoras domésticas desde $2009^{8}$, devido ao ingresso das mulheres em outras atividades propiciadas pelo aumento do nível educacional, o aumento do salário, ainda que a média de remuneração das trabalhadoras domésticas continue sendo menor que o salário mínimo 9 .

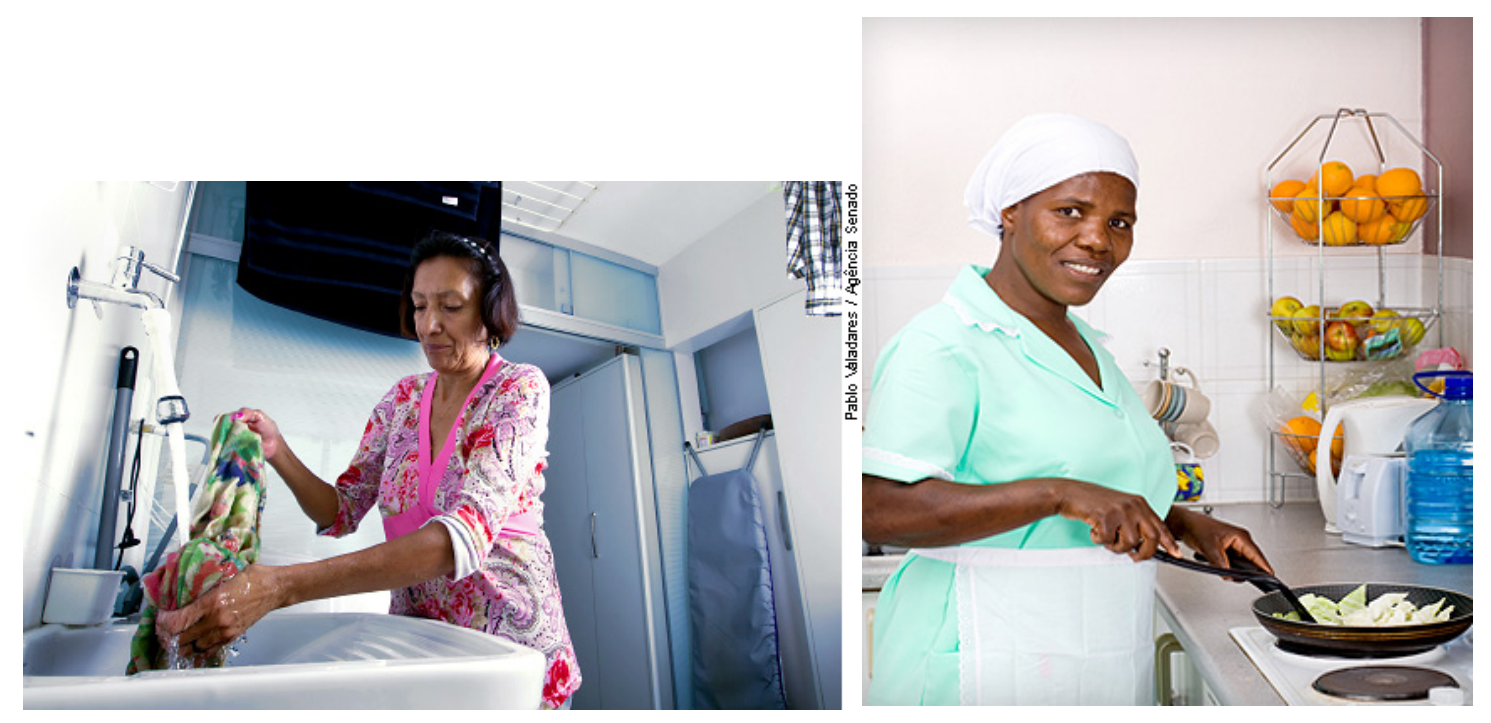

\footnotetext{
${ }^{7}$ Termo pronunciado pelo o Senador Randolfe Rodrigues (PSOL-AP) durante votação da PEC 66/2012 pela Comissão de Constituição, Justiça e Cidadania (CCJ) no dia 13 de março de 2013. Fonte: http://www.tudorondonia.com/noticias/pec-que-amplia-direito-de-trabalhadores-domesticos-vai-aplenario-na-terca-,35559.shtml. Acesso em: 01-04-2013, às 16h36.

8 Este era o tom das reportagens, ainda que estatisticamente o número não tenha sido alterado permanecendo de 2009 até o momento, em torno de 6 milhões de trabalhadoras.

${ }^{9}$ Fonte: http://www1.folha.uol.com.br/mercado/1208874-ganho-de-empregados-domésticos-sobe-56-emoito-anos-mostra-ibge.shtml.Acesso em: 01-04-2013, às 16h26.
} 
Figura 1: Foto 1: Pablo Valadares/Agência Senado ${ }^{10}$ Foto 2: sem autoria/Agência Senado ${ }^{11}$

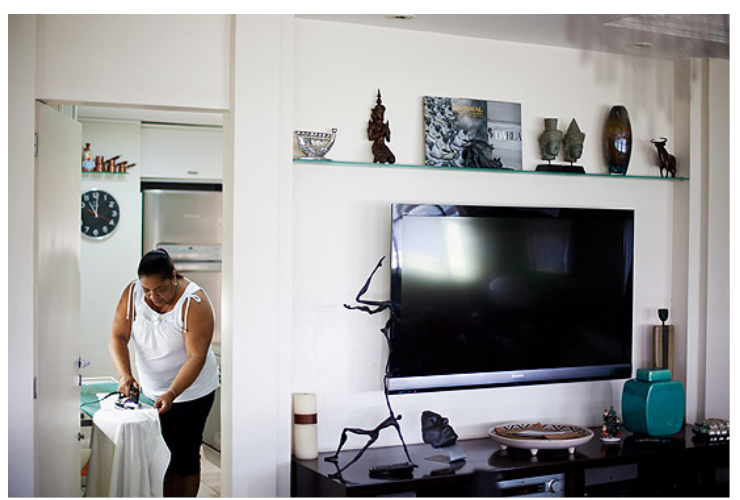

Figura 2: Foto 1: Daniel Marenco/Folhapress ${ }^{12}$

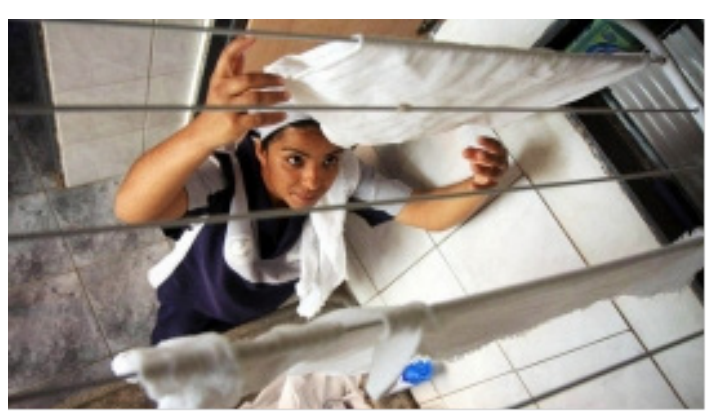

Foto 2: sem autoria/Revista Piauí ${ }^{13}$

Ao analisarmos as imagens utilizadas, quando se trata de reportagens sobre as mudanças legislativas no trabalho doméstico remunerado, a diversidade desta atividade também pode ser facilmente identificada, quando além dos afazeres domésticos como cozinhar, lavar, passar e varrer, também são colocadas na mesma categoria as atividades de cuidados com crianças ${ }^{14}$, idosos, deficientes e animais e também, em menor escala e, principalmente, desenvolvida pelo grupo minoritário da categoria, os homens, as atividades de vigia, motorista, jardineiro e caseiro. Todas as atividades exigem competências e habilidades bastante diferentes, mas pelo fato de serem desempenhadas no domicílio ou sob os interesses de uma família, são agrupadas de forma simplificada na categoria de empregados domésticos.

10 Imagem da reportagem de Marilia Coêlho, PEC das Domésticas começa a tramitar no Senado.Fonte:http://www.senado.gov.br/atividade/materia/detalhes.asp?p_cod_mate=109761. Acesso: $01 / 04 / 2013$, às $15 \mathrm{~h} 27$.

${ }^{11}$ Imagem da reportagem sem autoria. PEC 66-2012 Garantirá aos empregados domésticos os mesmos direitos que possuem os demais trabalhadores. Fonte: http://votenaweb.com.br/arquivo/pec-66-2012. Acesso: 01/04/2013, às 15h40.

${ }^{12}$ Imagem da reportagem de Pedro Soares. Ganho de empregados domésticos sobe 56\% em oito anos, mostra IBGE. Fonte: http://www1.folha.uol.com.br/mercado/1208874-ganho-de-empregados-domésticossobe-56-em-oito-anos-mostra-ibge.shtml.Acesso em: 01-04-2013, às $16 \mathrm{~h} 26$.

13 Doméstica contrata jornalista para trabalhar como diarista. Fonte: http://revistapiaui.estadao.com.br/blogs/herald. Acesso em: 03-04-2013, às 11h25.

${ }^{14}$ Em matéria de Paula Sampaio, publicada no Estadão em 27 de março de 2011, tivemos conhecimento que no Brasil, há pelo menos cinco anos, foi criado por empregadoras de famílias nobres de São Paulo o GATB - Grupo Anti-Terrorista de Babás, em que as primeiras trocam e-mails sobre suas funcionárias, expressando o quanto têm apreço por aquelas que "aceitam tudo", e indignam-se quando uma delas demanda o pagamento de feriados trabalhados devido à sua "falta" de gratidão. Fonte: http://www.estadao.com.br/noticias/impresso,maes-criam-grupo-antiterrorismo-contra empregadas,697782,0.htm. Acesso em: 13/08/2013, às 10h46. 

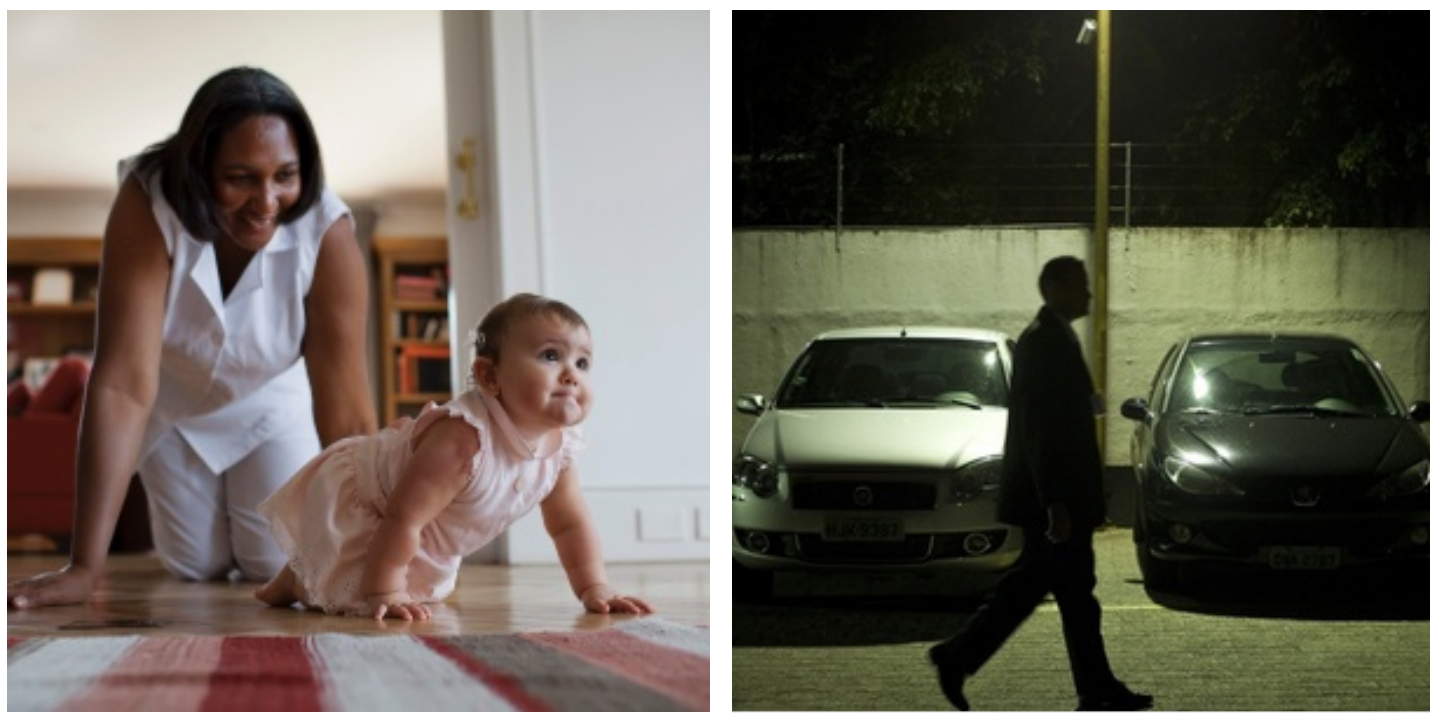

Figura 3: Foto 1: Lalo de Almeida/The New York Times ${ }^{15}$ e Foto 2: Patricia Stravis/Folhapress ${ }^{16}$

Do outro lado, encontramos matérias que colocam os patrões como a categoria mais impactada pela equiparação dos direitos, muitas vezes, sob a assertiva de que essa novidade gerará desempregos e o segmento mais prejudicado será o das trabalhadoras. Um exemplo dessa vertente foi a reportagem de Joel Pinheiro da Fonseca ${ }^{17}$, publicada em 10 de janeiro de $2013^{18}$, logo após a chegada da PEC66 para apreciação no Senado, intitulada: O extermínio das empregadas domésticas, em que através da imagem de uma mulher branca, com aparência incomodada por estar realizando atividades domésticas, o autor critica a PEC66 argumentando que o mercado já estaria regulamentando o valor pago ao trabalho doméstico de maneira mais eficaz que as leis trabalhistas instituídas pelo Estado, que apenas serviriam para intensificar o antagonismo de classes, minar relações sustentadas na confiança, além de gerar mais desemprego e informalidade.

\footnotetext{
${ }^{15}$ Imagens presentes no artigo Comissão aprova proposta que regulamenta trabalho doméstico. Fonte: http://noticias.uol.com.br/empregos/ultimas-noticias/2013/06/06/comissao-aprova-proposta-que regulamenta-trabalho-domestico.jhtm a. Acesso em: 11/06/2013, às 10h25.

${ }^{16}$ Idem.

${ }^{17}$ Joel Pinheiro da Fonseca é mestrando em filosofia, editor da revista Dicta\&Contradicta e escreve no blog Ad Hominem.

${ }^{18}$ Fonte: http://www.mises.org.br/Article.aspx?id=1497. Acesso em: 01-04-2013, às 16h06.
} 


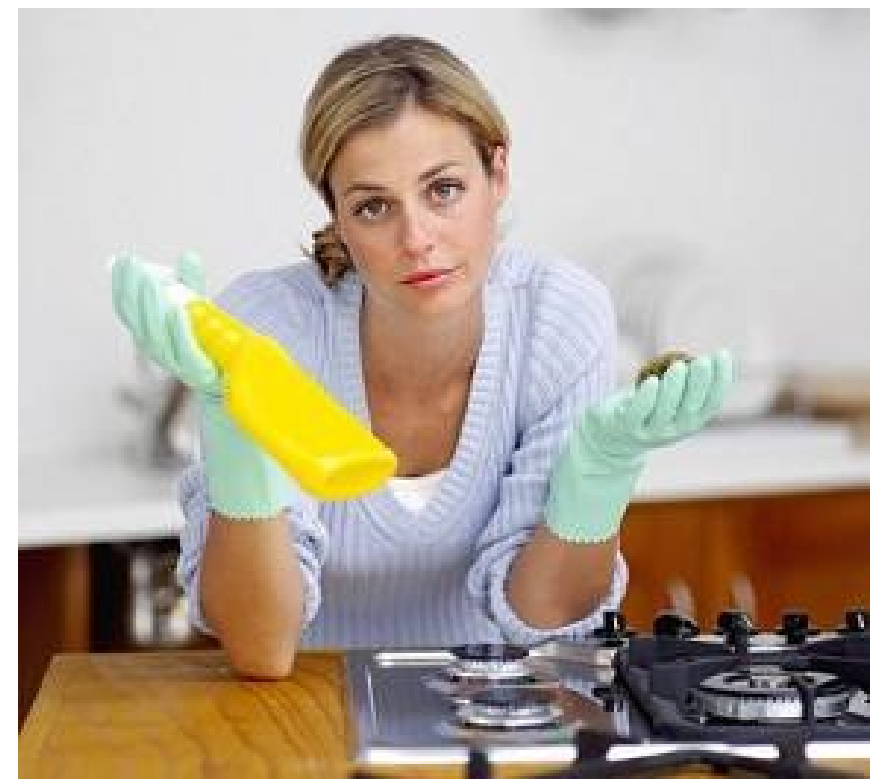

Figura 4: Imagem de empregadora: sem autoria

Discutindo sobre a obrigatoriedade do Fundo de Garantia por Tempo de Serviço FGTS e de horas extras, ele argumenta que o pagamento deste encargo pelos patrões infantilizaria as trabalhadoras, como se fossem incapazes de guardar dinheiro ou não pudessem ter autonomia para escolher gastá-lo todo; e que apenas quem se beneficiaria deste fundo seria o governo, por ele ser armazenado no banco público da Caixa Econômica Federal e não possuir os mesmos rendimentos dos bancos privados. Desse modo, além de provocar a redução da remuneração imediata das domésticas, o pagamento deste encargo dificultaria a contratação de mulheres com poucas habilidades e experiência, posto que os patrões não estariam dispostos a pagar um salário mínimo mais encargos trabalhistas pelos seus serviços. Como decorrência Joel afirma:

Casas ficarão mais sujas, mulheres e homens (mas especialmente mulheres) trabalharão menos fora de casa elou terão menos tempo de lazer; e mulheres pobres desejosas de uma oportunidade de trabalho que demande baixíssima qualificação terão mais dificuldades em encontrar um patrão. Sua pobreza será mais duradoura. Todos saem perdendo.

Sem questionar a naturalização do trabalho doméstico voltado as mulheres, o autor soluciona a necessidade de realização de tais atividades pela contratação de mulheres pobres, que sem outras alternativas, deveriam sentir-se felizes por encontrar um emprego que demandaria baixíssimas qualificações. Além de defender as relações baseadas na confiança e nas trocas de favores e não a partir da regulamentação e fiscalização do Estado, deixando as trabalhadoras vulneráveis em relação aos desígnios 
e vontades dos patrões, Joel defende que a nova Lei transformaria a relação de trabalho em um cabo de guerra em que uma parte busca tirar mais da outra dando o mínimo possível. Contrariando pesquisas e relatos de trabalhadoras que evidenciam justamente essa realidade de exploração propiciada pela ausência de proteção social para a categoria.

Ao não fazer uma análise mais abrangente sobre quais fatores propiciam a existência de algumas mulheres dispostas a realizar os afazeres domésticos e outras a pagar por ele, ou ainda por quais motivos foram atribuídas somente às mulheres essa responsabilidade, o autor se exime de propor caminhos que visem uma análise responsável sobre a realidade brasileira. Muito pelo contrário, partindo de pressupostos liberais, em que o mercado seria responsável por agregar valor ao trabalho, Joel se posiciona como se todos tivessem as mesmas oportunidades de crescimento econômico, ou pior, como se as mulheres pobres não tivessem que exigir condições de trabalho e remunerações melhores, sob o risco de ficarem desempregadas e/ou na informalidade.

Contrariando e questionando os pressupostos desta análise é que propomos um estudo e análise que vão de encontro aos argumentos de tal autor, posto que temos ciência de que "o argumento de que qualquer benefício às trabalhadoras domésticas redundará numa diminuição de empregos é recorrente ao longo do tempo" (BernardinoCosta, 2007:237).

Esta justificativa do desemprego em conjunto ao caráter afetivo das relações estabelecidas no emprego doméstico também foi mencionada durante a votação da PEC 66/2012 pela CCJ, no dia 13 de março de 2013, pelo senador José Agripino (DEM/RN), que alertou para os "danos" que a lei traria para as relações patrão-empregado, a diminuição dos empregos e o aumento de reclamações trabalhistas ${ }^{19}$.

De maneira sarcástica, algumas reportagens identificam a inserção de profissionais com Ensino Superior que estariam ingressando no emprego doméstico devido aos direitos adquiridos pela categoria, como foi o caso do jornalista Lauro Paladino que teria colocado seu currículo na caixa de correio do seu prédio, com suas experiências de trabalho, qualificação e fluência em quatro idiomas, e sido contratado por uma doméstica ${ }^{20}$. Essa historieta é publicada no sentido de criticar os direitos alcançados pela categoria, argumentando que, quem não realizava atividades

\footnotetext{
${ }^{19}$ Fonte: http://www.tudorondonia.com/noticias/pec-que-amplia-direito-de-trabalhadores-domesticos-vaia-plenario-na-terca-,35559.shtml. Acesso em: 01-04-2013, às $16 \mathrm{~h} 36$.

${ }_{20}$ Doméstica contrata jornalista para trabalhar como diarista. Fonte: http://revistapiaui.estadao.com.br/blogs/herald. Acesso em: 03-04-2013, às 11h25.
} 
domésticas, depois da lei provavelmente terá que fazer; além de chamar atenção para outras profissões, como a de jornalistas que também seriam precárias em termos de direitos, como se avançar nos direitos de uma categoria estivesse em contraposição aos avanços de outra.

Outra ideia contrária e bastante recorrente relativa à equiparação dos direitos das trabalhadoras domésticas é de que os empregadores são famílias e não empresas ${ }^{21}$.

Se parte da caracterização do trabalho doméstico como um trabalho especial, mas ao invés de considerar suas particularidades em prol dos direitos das trabalhadoras, se utilizam para privilegiar as necessidades dos empregadores com o argumento de que o lar não pode ser regido pelas mesmas normas de uma empresa [...] (Goldsmith, 2012: 44)

Ainda assim, de 2006 a 2012, através da Lei 11.324 houve dedução no imposto de renda da contribuição paga pelo empregador à Previdência Social do empregado doméstico. Na Lei Complementar 150/15, através do Simples Doméstico que reúne todos os encargos do empregador, o INSS anteriormente de $12 \%$ sobre o salário pago, passou a ser de $8 \%$ e redução do imposto de renda para empregadores que o declaram de forma completa, desse modo, também contribuindo contra o aumento excessivo do custo do serviço doméstico.

Medidas como a Lei 150/15 são fundamentais para melhorar as condições materiais, mas também psicológicas e da forma como as TDs se pensam, repetidamente desvalorizadas, humilhadas e mesmo desumanizadas, como na polêmica questão da prova do ENEM - Exame Nacional do Ensino Médio de 2013, em que a pergunta sobre a presença ou não de trabalhadora doméstica associava-se à presença de bens materiais $^{22}$. Contudo, a mesma questão estava presente desde 2008 e apenas passou a ser questionada, coincidentemente, após a PEC das domésticas.

Figura 5: Imagem de questão do ENEM/2013

\footnotetext{
${ }^{21}$ Argumento presente na Reportagem já citada de Pedro Soares.

22 Fonte: http://oglobo.globo.com/educacao/enem-2013-mec-decide-alterar-pergunta-inadequada-sobredomesticas-em-questionario-8549036. Acesso em: 31/05/2013 às $12 \mathrm{~h} 34$.
} 


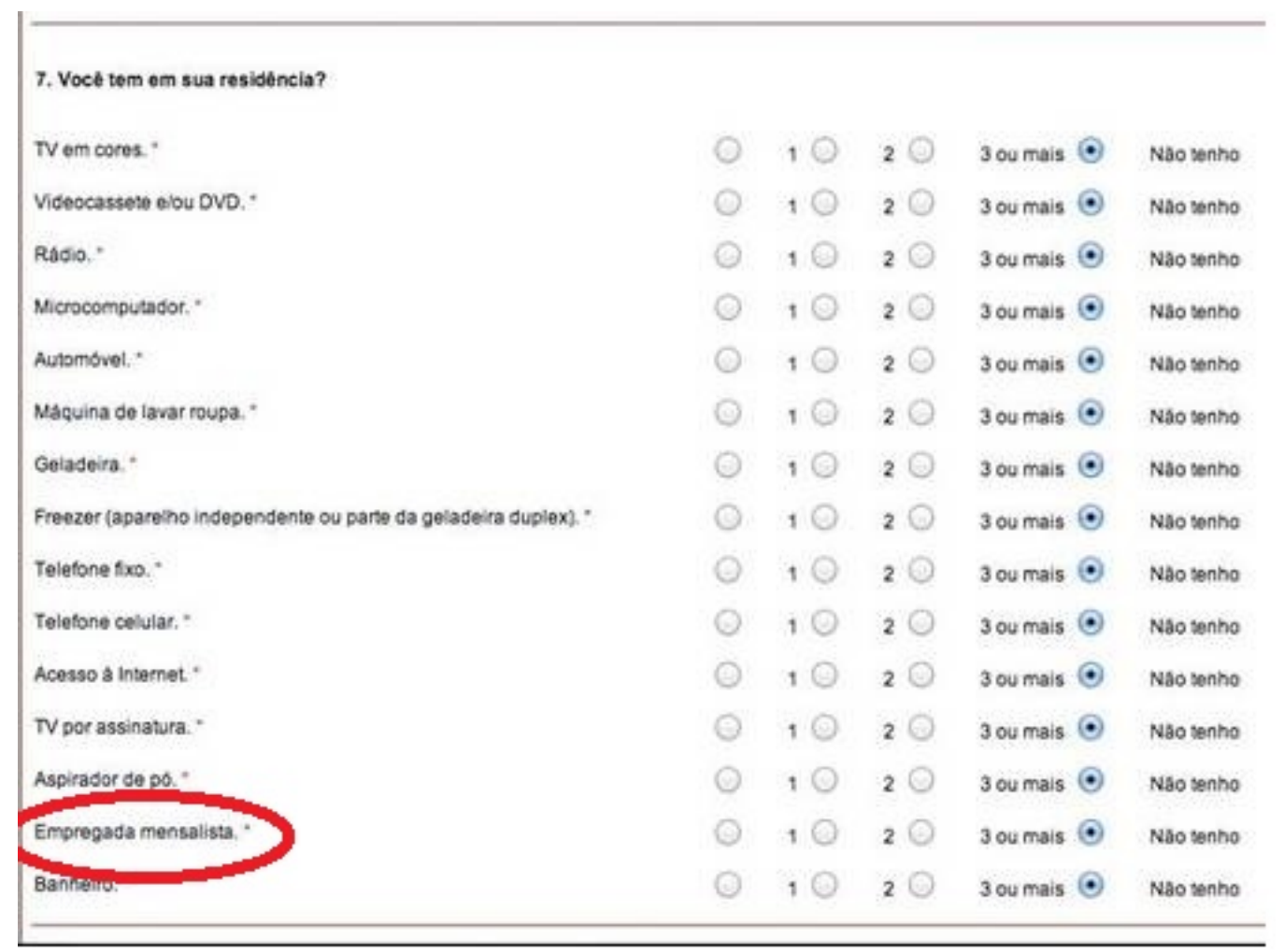

Outra situação importante diz respeito à criação de uma página no Twitter $^{23}$ denominada@aminhaempregada, criada por um profissional de marketing, paulista, de 33 anos, que não quis se identificar. Segundo o autor da matéria Ricardo Senra ${ }^{24}$, da BBC Brasil, o marketeiro teria criado a página para explicitar o racismo e o preconceito presentes na sociedade brasileira, com o objetivo de apontá-los àquelas pessoas que não teriam identificado essas posições discriminatórias em si mesmas. Em $48 \mathrm{~h}$ a página teria ganhado mais de 2,6 mil seguidores.

\footnotetext{
${ }^{23}$ O Twitter é uma rede social, criada em 21 de março de 2006, nos Estados Unidos.

${ }^{24}$ Fonte:http://www.bbc.co.uk/portuguese/noticias/2014/05/140520_salasocial_minhaempregada_rs.shtml. Acesso em: 21-05-2014, às 13 h37.
} 
Radicalizando o Imaginário: Impactos das transformações do trabalho...

Figura 6: .Imagens da página @aminhaempregada

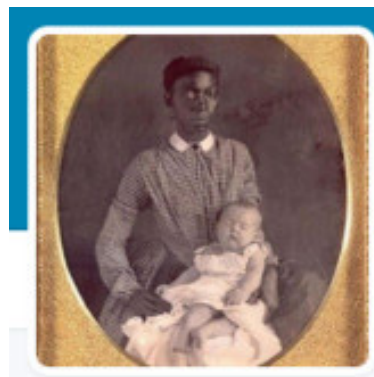

\section{A Minha Empregada}

\section{(1) aminhaempregada follows you}

A chibatada é serventia da casa (contém ironia e tristeza)

Tweet to A Minha Empregada

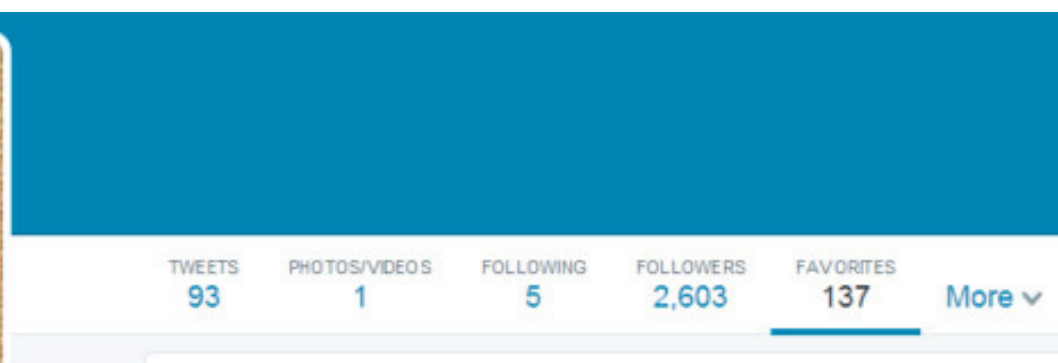

Favorites

P. ailton amaral @ailtonamaral - $11 \mathrm{~m}$

(Q) aminhaempregada o pior de tudo é ver que a maiorias dos racistinhas preconceituosos são jovens, que futuro nos espera?

Amanda Portella (2DraEvil - $19 \mathrm{~m}$

Para os amigues que acham que não existe mais preconceito no Brasil: sigam@aminhaempregada. Antropologia em estado bruto.

Toitser

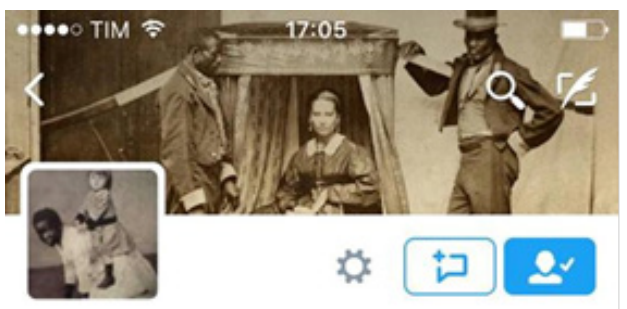

\section{A Minha Empregada}

(a) aminhaempregada

A chibatada é serventia da casa. (contém ironia e tristeza na batalha contra a imbecilidade e o preconceito).

$\vee$ Brasil Colonial

16 SEGUINDO $\quad \mathbf{1 8 . 4 5 1}$ SEGUIDORES

\begin{tabular}{|l|l|l|}
\hline Tweets & Midias & Favoritos \\
\hline
\end{tabular}

$*$ Tweet Fixado

A Minha Empregada @ami... 10/02/16 Olha a promoção!
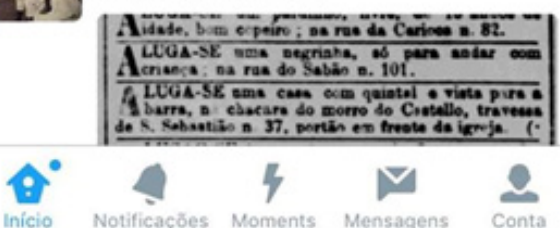
Atualmente a página conta com 18.451 mil seguidores e é composta tanto de denúncias a situações de racismo e discriminação a trabalhadoras domésticas, como de relatos que comprovam estas mesmas posições de forma deliberada.

Durante o ano de 2015, sobretudo após a publicação da Lei 150/15, vários casos de racismo ${ }^{25}$ e polêmicas envolvendo celebridades brasileiras também foram bastante repercutidos nas mídias e redes sociais. Um exemplo é o caso da atriz e apresentadora Fernanda Lima que postou uma fotografia em sua página virtual com duas babás negras e de uniforme branco na praia e foi bastante criticada ${ }^{26}$ e também a foto publicada pela atriz Carolina Dieckmann, em que ela e a atriz Regina Casé, posam com as trabalhadoras uniformizadas que trabalharam na noite de natal ${ }^{27}$, por reproduzir o formato racista da sociedade brasileira em que para as mulheres negras parece ser apenas reservadas posições de trabalhadoras domésticas e de atividades manuais e mal remuneradas.

Figura 7: Fotografias celebridades e trabalhadoras domésticas
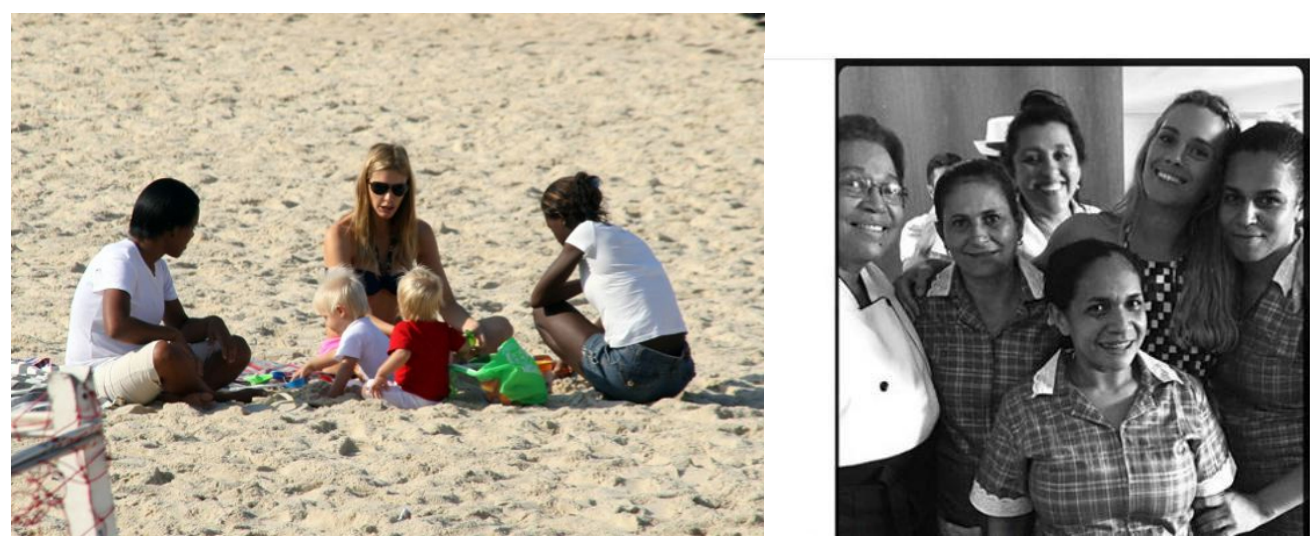

Foto 1: sem autoria e Foto 2: reprodução Instagram

Insistimos nas maneiras como as trabalhadoras domésticas são construídas e representadas imageticamente. Para além de reportagens que dizem respeito ao agenciamento da organização das trabalhadoras, elas são retratadas em seus ambientes de trabalho (casas de terceiros), realizando atividades domésticas e de cuidados e, quando fora da moradia dos patrões, os acompanhando portando um uniforme,

\footnotetext{
${ }^{25}$ Práticas discriminatórias pautadas pela ideia de inferioridade de raça/cor.

26 Fonte: http://www.pragmatismopolitico.com.br/2015/08/a-licao-que-fica-do-caso-fernanda-lima-e-asbabas-negras.html. Acesso em: 07/08/2015, às $21 \mathrm{~h} 47$.

27 Fonte: http://diariogaucho.clicrbs.com.br/rs/entretenimento/noticia/2015/12/foto-de-carolinadieckmann-e-regina-case-ao-lado-de-empregadas-domesticas-causa-polemica-4939687.html. Acesso: $30 / 12 / 15$, às $15 \mathrm{~h} 40$.
} 
Radicalizando o Imaginário: Impactos das transformações do trabalho...

frequentemente branco, para marcar sua diferença e desigualdade em relação aos empregadores, se estão com eles em um espaço público, o uniforme denota que é à trabalho. Dificilmente essas mulheres são abordadas em suas casas, com suas famílias, em ambientes de lazer ou mesmo de movimento político, reproduzindo as narrativas e formas de significação que os patrões constroem, mesmo quando são reportagens voltadas à aquisição dos direitos e protagonismo de luta e enfrentamento da condição do trabalho doméstico.

Em 2016, durante as manifestações que ocorreram no Brasil contrárias ao governo Dilma Rousseff, a fotografia de babás negras acompanhando seus patrões brancos durante as caminhadas chamaram atenção nas mídias, sendo a imagem recorrente e emblemática do racismo e das relações de poder no Brasil. Além disso, como a conquista da ampliação dos direitos da categoria realizou-se durante o governo petista, tornou-se uma marca de forte identificação com um governo voltado às camadas populares, enquanto a oposição estaria fortemente incomodada com a diminuição das desigualdades e o empoderamento da população negra, este argumento foi e continua sendo bastante utilizado em defesa do governo petista e como denúncia às motivações do grupo que foi às ruas para criticar e pedir o impeachment da presidenta. 

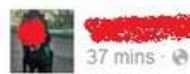

Até na folga a empregada trabalha realmente a burguesia fede, a

burguesia quer ficar rica, enquanto houver burguesia, não vai haver

poedia
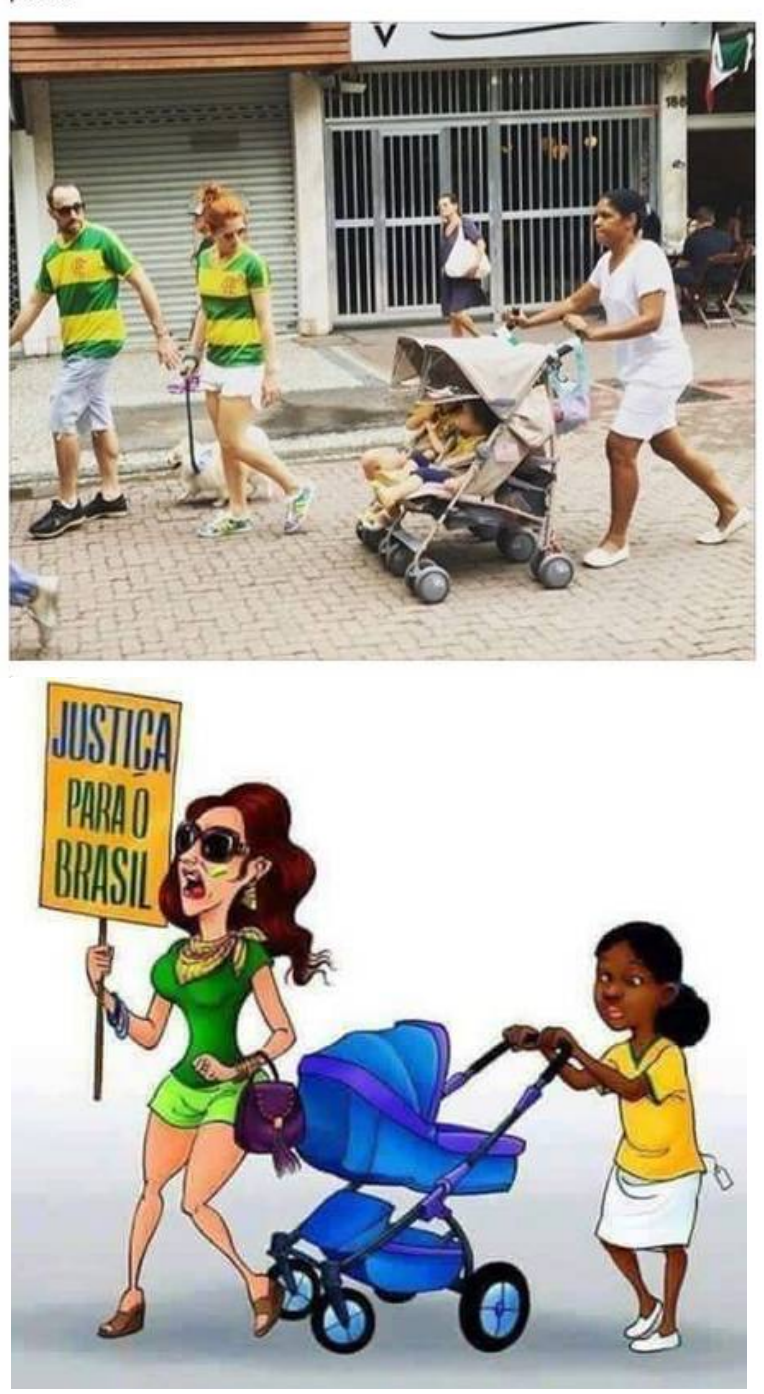

Figura 8: Imagens patrão/TD - Reprodução/Facebook 


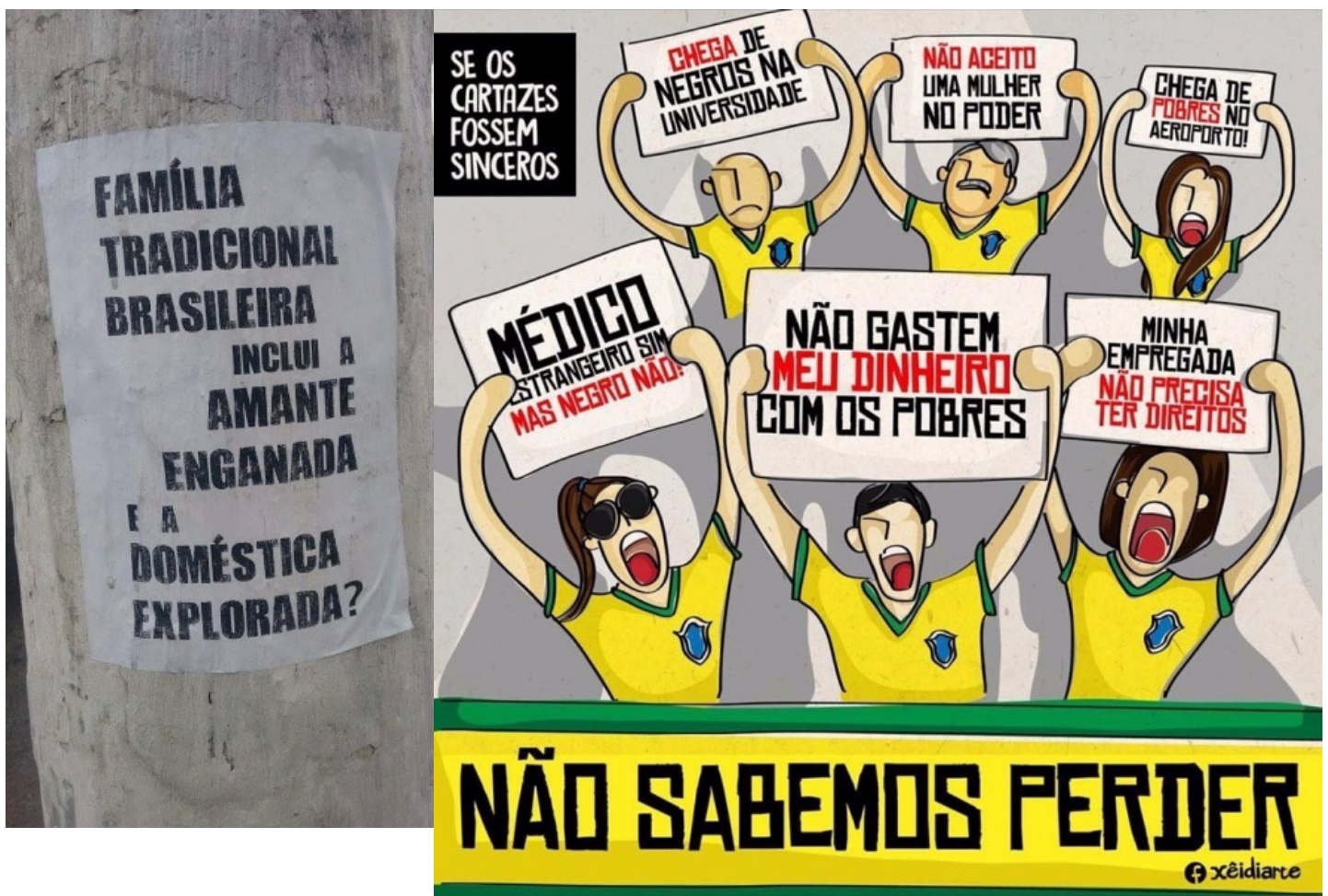

Figura 9: Imagens referentes ao TDR - Reprodução Facebook

Outras evidências de que no cenário brasileiro o trabalho doméstico remunerado está diretamente atrelado à sua realização por mulheres negras é que comumente quando uma dessas mulheres ocupa espaços de maior prestígio social são fortemente agredidas com alegações de que deveriam estar realizando atividades domésticas e não em tais espaços. Apenas com dois exemplos, podemos citar o caso de médicas cubanas que vieram trabalhar no país pelo programa Mais $\operatorname{Médicos}^{28}$ e que, segundo a jornalista Micheline Borges, teriam "cara de domésticas" e não de médicas ${ }^{29}$. Também o caso da senadora, piauiense, Regina Souza, negra e nordestina, chamada pelo humorista branco, Danilo Gentili, de a tia do cafezinho ${ }^{30}$.

\footnotetext{
${ }^{28}$ www.programamaismedicos.gov.br;

${ }^{29}$ Fonte: http:/g1.globo.com/rn/rio-grande-do-norte/noticia/2013/08/jornalista-diz-que-medicas-cubanasparecem-empregadas-domesticas.html. Acesso em: 28/08/2013, às19h25.

30 Fonte: http://www.brasilpost.com.br/2016/05/12/danilo-gentili-tia-do-cafe-senadora_n_9931012.html. Acesso: 13/05/2016, às 19h33.
} 


\section{Micheline Borges}

Me perdoem se for preconceito, mas essas medicas cubanas tem uma Cara de empregada domestica. Será que São medicas Mesmo??? Afe que terrivel. Medico, geralmente, tem postura, tem cara de medico, se impōe a partir da aparência... Coitada da nossa população. Será que eles entendem de dengue? E febre amarela? Deus proteja O nosso Povol

hà 2 I hora Natal (Rio Grande do Norte) (2)

3 pessoas curtiram isso

Desce quando aparência tem a ver com competência? desde quando empregada doméstica tem uma cara? Medico tem cara? Jornalista tem cara? Ta na cara que alguém é bombeiro ou farmaceutico? Aqui no Ceará, a gente olharia pra ti e diria: $\hat{e} \hat{\theta}$ há 59 minutos via celular - 1 ile 1

Micheline Borges Então, vamos

Lá você vai trabalhar descabelada, de Chinelos e sem

Lavar a cara? Vou mais Adiante: será. Ver mais

hà 47 minutos vis celular - ille 1

Figura10: Imagem - Página Micheline Borges: Reprodução/Facebook

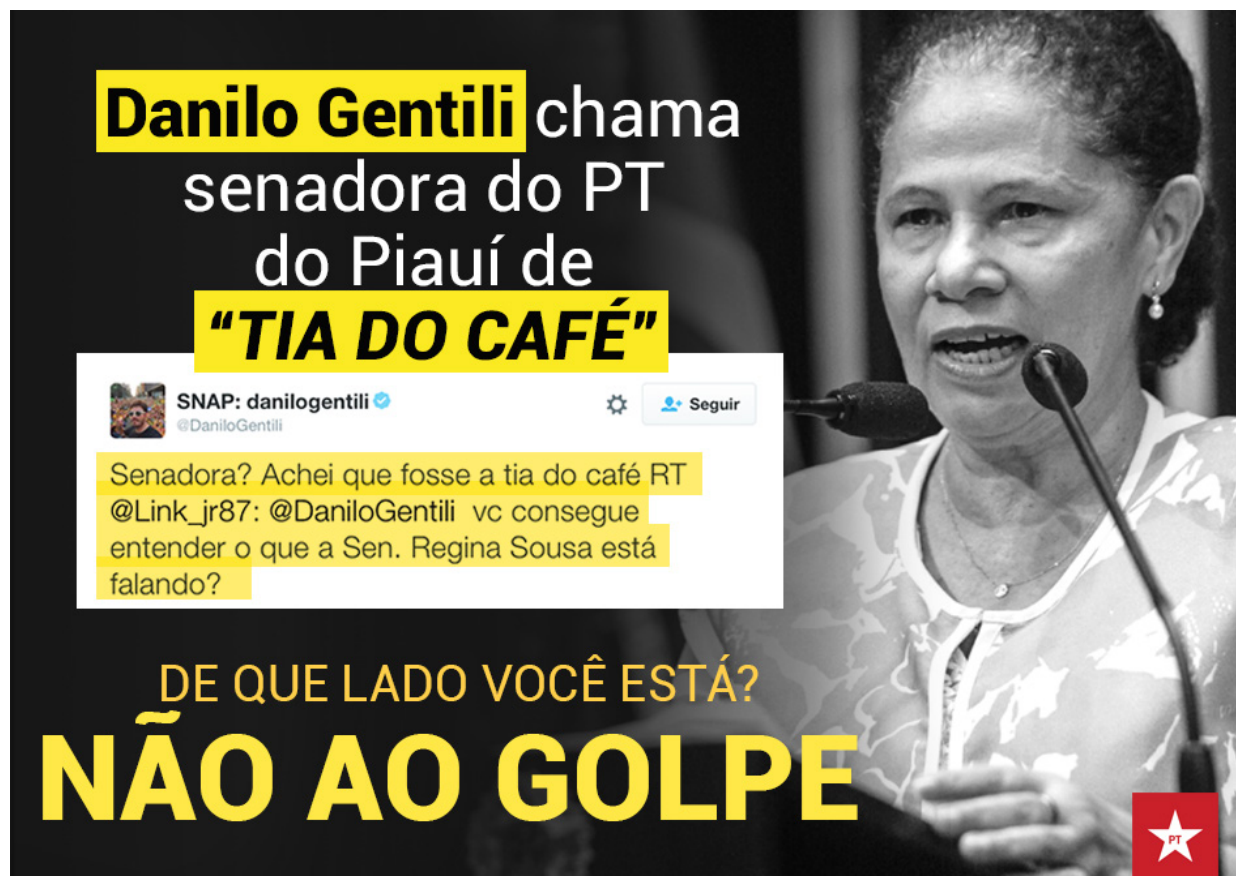

Figura 11: Imagem postagem Danilo Gentili: Reprodução/Facebook 
Radicalizando o Imaginário: Impactos das transformações do trabalho...

A centralidade da temática na contemporaneidade - Imagens do trabalho doméstico remunerado (suporte videográfico)

Na década de 2000, principalmente com o surgimento da "PEC das domésticas" (2012), intensificou-se as reportagens vinculadas pelas mídias e o debate público a respeito das trabalhadoras domésticas; começaram a ser lançados também vários filmes sobre as dinâmicas das famílias no contexto brasileiro, em que a presença da trabalhadora doméstica, comumente tida como naturalizada, é colocada de forma central, com o intuito de dar visibilidade a estas mulheres, seja evidenciando a diversidade de configurações que o emprego doméstico pode tomar, como no caso do filme Domésticas (2001), que decorreu de uma peça de Renata Melo, e Doméstica (2012), em que sete adolescentes registraram a semana de suas trabalhadoras domésticas; seja para retratar as mudanças do país no que diz respeito a ampliação da escolaridade e a presença de políticas sociais que têm propiciado o ingresso de negros, não-brancos e pobres em espaços dantes interditos para estes segmentos, como as universidades e órgãos públicos, como no caso de Que horas ela volta? (2015).

O filme Domésticas (2001), 1h30, dirigido por Fernando Meirelles e Nado Olival é uma comédia baseada na peça homônima de Renata Melo, que também é roteirista e atua no filme como atriz. Apesar de se propor como uma comédia, o filme retrata diferentes configurações do trabalho doméstico atuantes no cenário brasileiro e a trama gira em torno do sumiço da filha adolescente de uma doméstica e do entrelaçamento do cotidiano de cinco trabalhadoras na cidade de São Paulo. Elas são: Cida, Roxane, Quitéria, Raimunda e Créo. Partindo de nomes populares e frequentemente encontrados entre as trabalhadoras domésticas, Cida, por volta dos 40 anos, não-branca, trabalha como doméstica, mas mora em casa própria, juntamente ao marido, que não lhe dá bastante atenção e que acaba falecendo. Sua trajetória muda quando conhece o motorista da casa em que Créo trabalha e, após quase lhe atropelar, este lhe oferece uma carona e o flerte entre os dois dá início.

Créo é uma trabalhadora evangélica, também por volta dos 40 anos, negra, que dorme em um quartinho de empregada, bem pequeno, ao lado da cozinha da casa de seus patrões, apesar de possuir casa própria. Ela tem uma filha adolescente, também negra, que começa a trabalhar de babá do filho da patroa da mãe, que fica contente com o trabalho da filha. Contudo, em um dia de trabalho, ao brincar com a criança no 
balanço da praça em frente ao edifício da patroa, a menina tira seu uniforme branco e decide fugir com o namorado em busca de outro destino que não o da mãe.

O ônibus se apresenta como um local de forte sociabilidade entre as domésticas ${ }^{31}$, local em que se encontram e conversam sobre os acontecimentos do dia. Roxane, mais nova, por volta dos 30 anos, branca, trabalha como doméstica, mas sonha em ser modelo, pois parece adquirir os atributos de beleza necessários para tal. Quando consegue poupar um dinheiro, faz umas fotografias na esperança de conseguir um novo trabalho; enganada, ela depara-se em uma situação de prostituição, primeiramente decepcionada, mas depois exercendo o trabalho como uma alternativa para aumentar sua renda.

Sua amiga Quitéria aparenta ser a mais nova entre as protagonistas, é negra e é caracterizada como distraída e ingênua, tendo grande rotatividade nos empregos devido a sua distração, contudo é continuamente ajudada pelas amigas na aquisição de novos trabalhos. Já Raimunda é branca e sonha em casar, fantasiando relacionamentos amorosos com vários rapazes presentes em seu cotidiano, até conhecer um que trabalhava de faxineiro no prédio em que Roxane e Quitéria trabalhavam, apaixonar-se, mas como ele decide entrar para o crime, ela acaba casando-se com o melhor amigo do primeiro.

O filme é muito interessante no que diz respeito à variedade de atividades e formas de emprego que a categoria das trabalhadoras domésticas assume, seja dormindo no local de trabalho ou voltando para suas residências próprias. Também reflete as diferentes atividades que são desempenhadas por tais trabalhadoras: cozinhar, cuidar de crianças e animais, passar roupas, arrumar e limpar casas, carros dos patrões, entre outras. Além disso, chama atenção para o ônibus como local de sociabilidade e também o local de trabalho, um apartamento, onde se desenvolvem redes de ajuda e solidariedade entre as domésticas.

A religião evangélica, que também é bastante presente no cotidiano das trabalhadoras, é mencionada, atribuída a uma doméstica bastante conformada com sua realidade, mas que entra em conflito com a filha mais nova que não aceita seguir a trajetória da mãe. Para fugir do trabalho doméstico, também percebemos o empreendimento de Roxane em tornar-se modelo (mesmo que termine por se prostituir) e Raimunda, que projeta no casamento um futuro melhor.

${ }^{31}$ Como na pesquisa de Caldas (2012). 
Radicalizando o Imaginário: Impactos das transformações do trabalho...

Entretanto, o caso de Quitéria, que no filme é retratado como o mais hilário, nos inquieta por voluntariamente ou não, chamar atenção para o racismo presente nas relações sociais no Brasil. Quitéria é a mais escura das domésticas e coincidentemente é a mais distraída e ingênua, para não falarmos de burra e tapada, categorias bastante presentes nos discursos dos patrões em relação às funcionárias que não realizam as atividades como eles esperam, ou como argumento para explicarem o porquê de as trabalhadoras não terem seguido os estudos. Quitéria, a lesa, e Créo são as duas trabalhadoras negras, uma não consegue desempenhar suas atividades à contento e é repetida vezes demitida e a outra não questiona a desigualdade de sua posição, concentrando suas esperanças de uma vida melhor na religião evangélica. Entretanto, a filha adolescente de Créo, também negra, rompe o que seria uma trajetória similar à da mãe, chamando atenção para o recorte geracional, em acordo com os dados sobre o trabalho doméstico no Brasil, em que a categoria se torna cada vez mais velha, e as novas gerações estão inserindo-se em outros setores de trabalho.

As outras três personagens, mais embranquecidas, são as que conseguem escapar ao trabalho solitário e repetitivo, seja através do casamento ou ao exercício da prostituição. De uma forma ou de outra, o filme é bastante interessante por retratar diferentes imagens associadas e vivenciadas no trabalho doméstico remunerado em contextos urbanos, além de utilizar-se de falas e relatos verídicos de trabalhadoras.

Figura 12: Capa e atrizes protagonistas do filme Domésticas (2001)

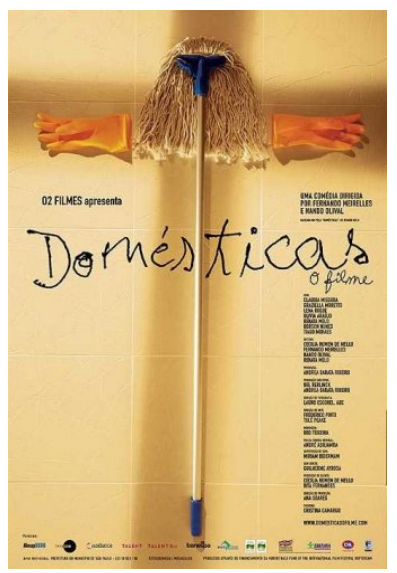




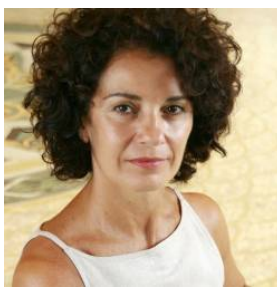

Cida

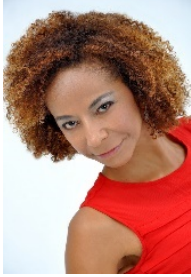

Créo

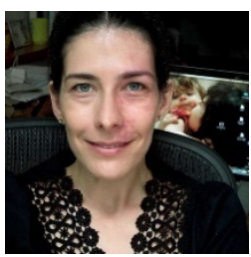

Roxane

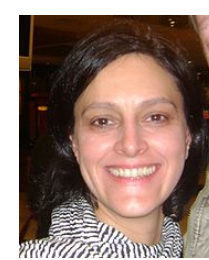

Raimunda

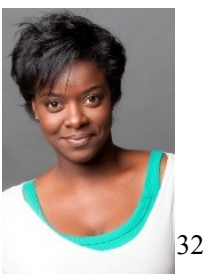

Quitéria

Renata Melo

Graziella

Mareto

Claudia

Olívia

Missura

Araújo

Com uma outra proposta, o documentário dirigido por Gabriel Mascaro, Doméstica (2012), lançado no ano da PEC das domésticas, foi construído a partir de imagens registradas por sete adolescentes sobre o cotidiano das domésticas que trabalhavam em suas casas, durante uma semana. A partir do material bruto o diretor construiu o longa-metragem de 1h16. Diferentemente de Domésticas (2001) ou de Que horas ela volta? (2015), neste caso não há atrizes e atores, mas sim membros da família empregadora, muitas vezes, criados pelas trabalhadoras, que nutrem grande afeto por esses jovens e que são abordadas por eles, para que seu trabalho seja retratado e elas possam relatar um pouco as suas trajetórias de vida e como avaliam seu cotidiano. Dessa forma, o diretor consegue obter imagens privilegiadas que possivelmente não teria acesso, primeiro por não possuir uma relação próxima com as domésticas e depois porque sendo empregadores de camadas médias ou altas (com exceção de um caso), seria difícil obter a permissão de filmar o interior dessas casas e famílias. Contudo, esse privilégio também explicita uma relação de poder, em que as trabalhadoras concordam em ser filmadas, porque os adolescentes pedem, mas, pelo menos não aparece no filme, terem ciência dos usos e impactos que essas imagens tomarão ${ }^{33}$.

O documentário percorre algumas capitais brasileiras como Recife, Salvador, São Paulo e Rio de Janeiro, em que apesar da diversidade, percebemos cotidianos bastante semelhantes desempenhados pelas trabalhadoras. A primeira entrevista se passa em Recife, com a trabalhadora Vanusa, com aproximadamente 40 anos, não-branca, que trabalha há 17 anos na casa de Neto. Vinda de família pobre ela alegou que desde os 11 anos ajudava a mãe cuidando de alguma criança como babá e também realizando trabalho doméstico; mas aos 15 anos casou e parou de trabalhar, apenas retornando aos

\footnotetext{
${ }^{32}$ Imagens disponíveis em: http://www.adorocinema.com/filmes/filme-37050/. Acesso: 17/05/2016, às $11 \mathrm{~h} 48$.

33 Relações de poder que também estão presentes na relação pesquisador-entrevistado, devido as desigualdades sócioeconômicas, de status, mas também da autoridade textual do autor.
} 
24 anos. A casa em que trabalha pode ser considerada de camada alta, e além dela, aparecem no filme mais duas trabalhadoras (aparecem almoçando juntas) e Vanuza mostra seu armário alegando que era pequeno devido ela ter que dividir o espaço com as amigas. Além de empregada mensalista, Vanuza também é motorista da família há 10 anos, é separada, possui dois filhos e um deles é viciado em drogas, sendo um grande problema para ela. Se emociona ao falar do ex-marido, de quem gosta, mas segundo ela, não é valorizada, nem respeitada.

A segunda doméstica é Dilma, negra, que mora e trabalha na cidade de São Paulo, ainda que advinda de outro estado (provavelmente do Nordeste). Ela trabalha na casa de uma família judia e fala do estranhamento com a alimentação quando começou no emprego, pois sentia-se fraca. Mas diz que com o tempo foi aprendendo as receitas, gostando e atualmente faz até na sua casa para os familiares. Ela narra que sua chegada na cidade foi bastante traumática, pois casou-se, seu pai deu uma ajuda em dinheiro para o novo casal, mas ao se mudarem ela se deparou morando em um porão, sem poder sair, nem trabalhar, ameaçada pelo marido alcóolatra. Com o decorrer do tempo, ela sugere que tem filhos, mas não aprofunda o assunto, começou a trabalhar, mas também ressaltou que já foi bastante humilhada em outros empregos. Dilma aparece predominantemente cozinhando e percebemos outras trabalhadoras no lar; foi bastante filmada no sofá da sala e percebe-se que foi convidada para um ritual judeu chamado shabat $^{34}$ que ocorre à mesa, com a família empregadora, devido a filmagem para o documentário, oportunidade em que ela se mostrou muito feliz e grata.

A terceira trabalhadora é Gracinha, em uma casa menos abastada que as duas primeiras, na cidade de Salvador. A trabalhadora é negra e gosta muito de ouvir reggae, samba, e assistir futebol, fazendo questão de colocar o hino do Bahia e a camisa do seu time nas gravações. Ela mora no trabalho, dorme em um quarto pequeno, mas ressalta que o colchão é ortopédico. Gracinha realiza todos os afazeres domésticos da casa, cozinha, lava e limpa, além de cuidar da mãe da patroa, uma senhora idosa. Ela trabalha na casa há 13 anos, diz gostar do trabalho, mas que sente saudades de casa na solidão de seu quarto. Apesar de na maior parte da filmagem Gracinha se mostrar bastante alegre e bem-humorada, se emociona ao dizer que precisou passar três meses sem ir à sua casa pois a avó teria se operado, e nesse período seu filho foi assassinado sem que ela tivesse se despedido. Neste contexto percebemos a já discutida concentração de cuidados em

\footnotetext{
${ }^{34} \mathrm{O}$ dia de descanso semanal dos judeus, aos sábados.
} 
prol da família empregadora, enquanto muitas vezes, os filhos e parentes das domésticas ficam sem sua atenção.

O quarto caso é da jovem Lena, trabalhadora mais nova do grupo, negra, também de Salvador que vem para a casa da família empregadora devido seus pais trabalharem no sítio dos avós da patroa. A adolescente que lhe entrevista diz que considera Lena como uma irmã mais velha e que ela é como se fosse da família, apesar de ajudar na casa. Lena permite ser filmada, mas não dá nenhum depoimento. Ela tem uma filha recém-nascida que está sendo criada na casa, no quarto dos fundos onde as duas dormem. Na ausência de um relato de Lena, é sua patroa, branca, como todas das outras, quem diz que elas se ajudam, mas que sabe que a qualquer momento ela pode querer ir embora; mesmo que saibamos que com uma filha recém-nascida, provavelmente, sozinha, Lena não terá condições de sair tão cedo da casa.

Lucimar trabalha no Rio de Janeiro, é negra e amiga de infância de sua patroa, pois seus pais trabalhavam para os avós da empregadora, similar ao caso de Lena, e desde pequena as duas brincavam na cidade de Valença/RJ. A patroa relatou que ao ter o segundo filho e ficar sem babá, uma tia teria sugerido chamar Lucimar que estaria desempregada. Como a primeira trabalhadora Vanuza, Lucimar usa uniforme, mora na casa dos patrões em um quarto pequeno. Ela autoriza a gravação do seu trabalho: lava roupas, louças, arruma a casa, etc; e apesar de não falar muito, quando o adolescente pergunta se ela é feliz, ela hesita um pouco, talvez comparando a sua vida com a patroa, amiga de infância, e termina por dizer que o lado bom do trabalho é poder morar e passear no Rio de Janeiro, evitando maiores confrontos.

Os dois últimos casos são mais diferenciados, pois o primeiro se trata de Flávia, uma trabalhadora de uma empregada doméstica, na cidade de Salvador. Ela é branca, tem por volta dos 30 anos e diz já ter morado em São Paulo, quando foi agredida grávida pelo esposo e desde então não quis mais ter relacionamentos amorosos. Flávia é babá de Matheus, criança que possui uma deficiência, e também realiza todos os afazeres domésticos da casa, de camada popular. Já o último e único caso masculino é Sérgio, empregado doméstico e babá há 16 anos. Ele foi filmado cuidando de cachorros, lavando o banheiro, o quintal, lavando louças, estendendo roupas e também no seu pequeno quarto. Sérgio não se manifestou muito, mas sua patroa explicou que a antiga esposa o teria expulsado de casa por ele não ter emprego e ela o contratou desde então. Ele tem por volta de 60 anos e parece melancólico ao ouvir falar de sua família. 
Radicalizando o Imaginário: Impactos das transformações do trabalho...

Mesmo que saibamos que as filmagens e relatos foram produzidos por jovens empregadores sobre as trabalhadoras domésticas de suas casas, o documentário evidencia a predominância de mulheres negras em tais atividades, e o cotidiano repetitivo e na maioria das vezes solitário do trabalho doméstico, sempre acompanhado de um rádio ou televisão. Marcadas pelo uniforme, pelo quarto de empregada, ou pelos espaços em que circulam e utilizam da casa percebemos a dinâmica do trabalho e a desigualdades das trabalhadoras em relação aos patrões. Portanto, o filme retrata práticas contemporâneas do e no trabalho doméstico remunerado, além do estilo de vida de camadas médias e altas brasileiras, bastante pertinentes para as imagens sobre as trabalhadoras domésticas e o emprego que estamos estudando ${ }^{35}$.

Figura 13: Capa do Documentário Doméstica (2012)

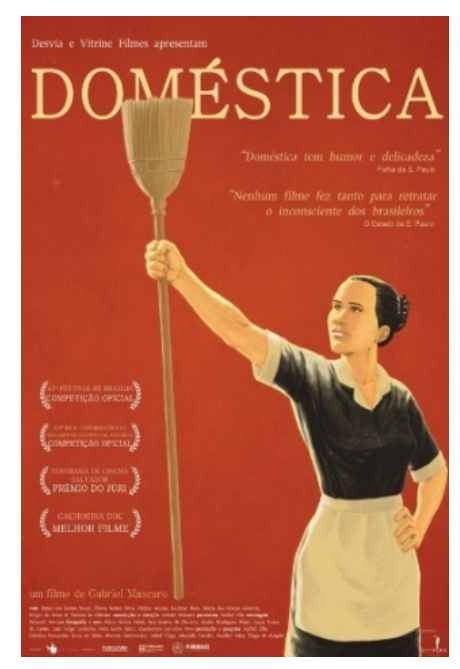

Antes de partirmos para o terceiro filme brasileiro que pretendemos discutir, é pertinente chamarmos atenção para a forte imagem da trabalhadora doméstica associada e construída pela presença da vassoura, que parece representar seu principal instrumento de trabalho. Além das duas capas dos filmes, também encontramos a vassoura na capa

\footnotetext{
${ }^{35}$ No contexto norte americano também encontramos o filme Histórias Cruzadas (2012), de Tate Taylor, que retrata o cotidiano, as situações de exploração e humilhação, e as trajetórias de trabalhadoras domésticas negras no sul dos Estados Unidos. Contudo, esses relatos são escritos por uma escritora branca. Isso é pertinente para pensarmos mais uma vez sobre as relações de poder e a legitimidade de fala, pois no filme percebemos que as trabalhadoras têm competências para expressar-se, mas devido uma situação de dependência e precariedade no trabalho e pelo fato de serem negras, não possuem a audiência necessária e que a escritora branca possui legitimando as versões das domésticas (ver Spivak, [1985]2010).
} 
do livro de Fraga (2013) e no título do livro de Devetter e Rousseau (2011) A vassoura. Ensaio sobre a faxina à domicílio e o retorno da domesticidade ${ }^{36}$.

Figura 14: Capa do livro de Fraga, 2013

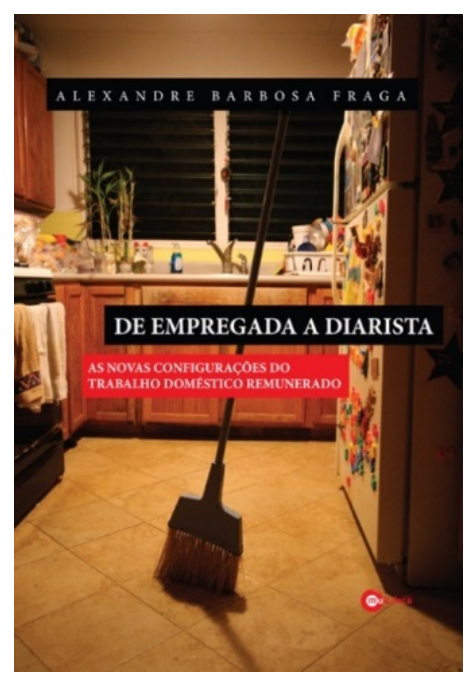

O premiado e polêmico Que horas ela volta? (2015), 1h54, de Anna Muylaert, é um drama lançado em meio a nova Lei das Domésticas (LC 150/2015), em que a protagonista $\mathrm{Val}$, encenada pela atriz Regina Casé, é oriunda do interior de Pernambuco, tendo deixado sua filha com os avós e vindo para São Paulo trabalhar como doméstica a tempo integral. Após 13 anos, e tendo ajudado a criar o filho da patroa, sua filha Jéssica lhe telefona pedindo ajuda para ir à São Paulo prestar vestibular.

Val encarna a típica trabalhadora doméstica nordestina que vai para São Paulo em busca de melhores condições de vida. Ela mora na casa dos patrões, sente saudade da filha que deixou em Pernambuco, manda dinheiro, mas acaba cuidando do filho da patroa, que possui a mesma faixa etária da filha. Aspecto bastante corriqueiro na trajetória de vida de trabalhadoras domésticas que necessitam deixar seus filhos com avós, familiares ou amigas, para ir trabalhar.

\footnotetext{
${ }^{36}$ Du balai. Essai sur le ménage à domicile et le retour de la domesticité.
} 
Após 13 anos, Val tem uma relação harmoniosa com os patrões, morando no quarto apertado e calorento dos fundos. Seu cotidiano é retratado predominantemente na cozinha ou na área dos fundos da mansão em que moram. A piscina, apesar de evidente, parece um espaço interdito ao uso de Val. A rotina da casa se transforma a partir da chegada de Jéssica, que tendo tido acesso à educação, questiona à mãe sua posição subserviente no interior da casa. Ao fazer uso de espaços e bens materiais considerados proibidos aos empregados pela patroa, e não questionados por sua mãe (como tomar o sorvete mais caro reservado à família), Jéssica provoca um conflito na dinâmica da casa, mas desperta em Val a identificação de situações de desigualdade, antes não questionadas e percebidas como naturais, ou seja, parte do papel que lhe cabia enquanto doméstica daquela casa.

Já incomodada com a presença da jovem, após Jéssica ter pedido para ficar no quarto de hóspedes e não no quarto apertado da mãe, tomado o sorvete da família e, considerado mais absurdo ainda, ter tomado banho de piscina com seu filho, sem mencionar de maneira explícita esses acontecimentos, a patroa pede que $\mathrm{Val}$ encontre um lugar para Jéssica morar. Neste contexto, o patrão e marido distante começa a nutrir atração pela menina. Algo também frequente nas narrativas das trabalhadoras, ainda que sem o caráter romântico, mas sim o assédio e abuso sexual vivenciado de forma violenta e pautado em uma visão de superioridade dos homens da casa em relação à trabalhadora doméstica, prática já presente no período da escravidão, quando as escravas eram tidas enquanto mercadoria ${ }^{37}$.

No decorrer da trama, Jéssica passa no vestibular para o curso de arquitetura da Universidade Federal de São Paulo, projeto da patroa de sua mãe para o próprio filho que não obtém êxito. A filha começa a estudar e a morar em uma casa na favela, enquanto a mãe, ao descobrir ser avó, decide deixar o emprego para trazer de Pernambuco e cuidar do neto, rompendo assim o ciclo que ela mesma praticou.

Ainda que a presença de trabalhadoras domésticas seja muito presente nas casas das famílias brasileiras, o filme chama atenção para o caráter ambíguo e conflituoso da relação entre patrões e empregadas, que apesar de possuir um caráter afetivo pela duração do emprego, a proximidade e desempenho do trabalho no ambiente doméstico, além de forte vínculo entre a trabalhadora e os filhos dos patrões; também é

\footnotetext{
${ }^{37} \mathrm{O}$ romance um defeito de cor (2015) de Ana Maria Gonçalves retrata o século XIX na Bahia, quando muitos africanos e africanas continuavam sendo trazidos da África e forçados a realizarem trabalhos na lavoura e domésticos, no regime escravocrata, sendo agredidos e humilhados cotidianamente, inclusive com o estupro das mulheres sendo prática frequente naquele contexto.
} 
caracterizado por forte desigualdade social, em que às trabalhadoras ficam relegados os piores cômodos da casa, além da alimentação de menor qualidade. Ela transita pela casa, mas não pode usufruir de todos os espaços e bens materiais.

Val está dentro de uma prática que de tão frequente é poucas vezes questionada por mulheres de sua geração, que tiveram o emprego doméstico como única opção de trabalho, posto que pobres e com baixa escolaridade. Já sua filha, ao prestar o vestibular, chama atenção para a possibilidade de mudança na profissão de doméstica e denuncia a exploração e condição de submissão vividas no emprego doméstico.

Em meio à regulamentação da Lei que visa equiparar os direitos das trabalhadoras domésticas aos demais trabalhadores, este filme, além de ganhar vários prêmios como os outros dois, provocou muitas discussões no cenário brasileiro e fora dele, com relatos de surpresa expressados por estrangeiros indignados com as práticas do emprego doméstico no Brasil. Contudo, também foram divulgadas algumas críticas em relação à ausência da problematização da dimensão de raça/cor no filme, já que Val e Jéssica, apesar de não-brancas, não foram interpretadas por atrizes negras; os membros da família empregadora, ao encontro das estatísticas, são brancos.

Figura 15: Capa do filme Que horas ela volta? E as protagonistas: Jéssica (Camila Márdila) e Val (Regina Casé) ${ }^{38}$
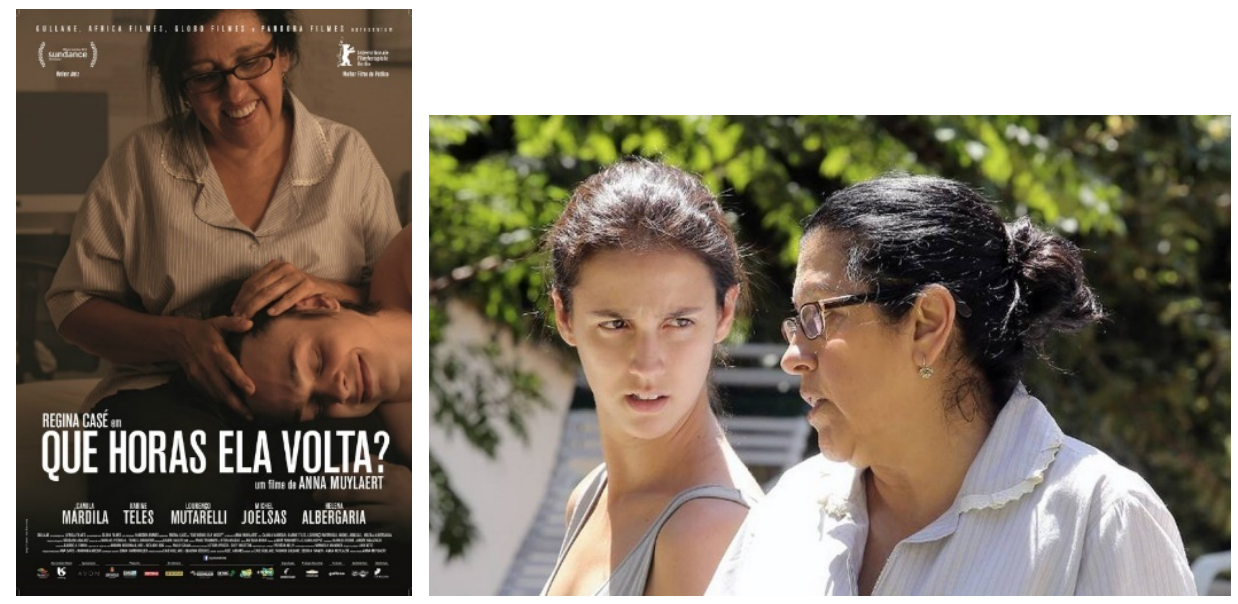

Com o objetivo de dialogar, apresentar e elaborar reflexões a respeito das imagens construídas por distintos suportes em relação às trabalhadoras domésticas e as atividades desempenhadas por elas, que no caso deste filme reflete o cuidado da 38 ch\&sa $=$ X\&sqi=2\&ved=0ahUKEwiyua-9zuHMAhWEhZAKHWAjD20Q_AUICCgD\&dpr=1. Acesso em: $17 / 05 / 2016$, às $14 \mathrm{~h} 18$. 
doméstica com o filho da patroa, buscamos contextualizar o cenário o qual estamos trabalhando e tratando, seja por meio de discussões acadêmicas, pela conformação de regulamentações, seja pelas e através das reportagens e filmes ${ }^{39}$ que centralizam a temática.

Considerações Finais - Radicalizando o imaginário: construções imagéticas de si de domésticas brasileiras

\begin{abstract}
Antes de ser o tempo passado que está em jogo, o que se coloca é a projeção do devir, no presente da narração que nos faz perscrutar o tempo passado. (...) Somos sempre as recapitulações de nós mesmos, ou o resultado da nossa vontade de fazer sentido com tudo o que nos aconteceu; somos a projeção dessas intenções, dessas expectativas, das antecipações, mas também dos atos de vontade que se expressam em que são sempre os projetos, em coisas por fazer (Eckert e Rocha, 2013:153; 230)
\end{abstract}

A etnografia da duração empreendida buscou a apresentação de imagens relativas ao mundo do trabalho doméstico a partir de diferentes suportes que, conjugados às maneiras como os encontros etnográficos me permitiram a produção de imagens durante a pesquisa de campo, nos falam desta mobilidade de imagens, mas também de imobilidades das formas que elas assumem. Como vimos, o trabalho doméstico é comumente construído pela imagem de uma mulher negra, uniformizada, realizando atividades domésticas e de cuidado. Além disso, a pobreza, a baixa escolaridade e a migração também são aspectos bastante explorados nos filmes e reportagens que tratam sobre o tema. Essas imagens podem estar de acordo com os dados estatísticos que compõem o perfil das trabalhadoras domésticas, mas vão de encontro às imagens que elas preferem construir de si.

Durante a realização de minha pesquisa de campo na cidade de Belém, a estratégia que utilizei com as trabalhadoras foi que elas mesmas selecionassem fotografias que elas avaliassem que falassem sobre elas e que poderiam ser a construção de suas trajetórias de vida. Temos a seleção de imagens construídas por Francisca e Hilda em que estão presentes membros de suas famílias biológicas e/ou de criação,

\footnotetext{
${ }^{39}$ No dia 24 de setembro de 2016 foi lançado um novo documentário em Porto Alegre, também com o título de Domésticas, no âmbito do projeto "Trabalho Doméstico: Construindo Igualdade no Brasil", parceria da ONU Mulheres - Fundo de Igualdade de Gênero com a THEMIS - Gênero Justiça e Direitos Humanos e o FUNDO ELAS. Dirgido por Felipe Diniz e realizado pela Casa de Cinema de Porto Alegre. Nele há relatos de três trabalhadoras: Creuza, Djanira e Marilisa, sobre suas vivências e opiniões acerca do trabalho doméstico.
} 
alguns empregadores, mas sobretudo amigos, em situações em que elas estão participando de festividades e lazer, em imagens bastante distantes daquelas que frequentemente se referem às trabalhadoras e ao emprego doméstico.

Figura16: Fotografias da trajetória de Francisca selecionadas por ela

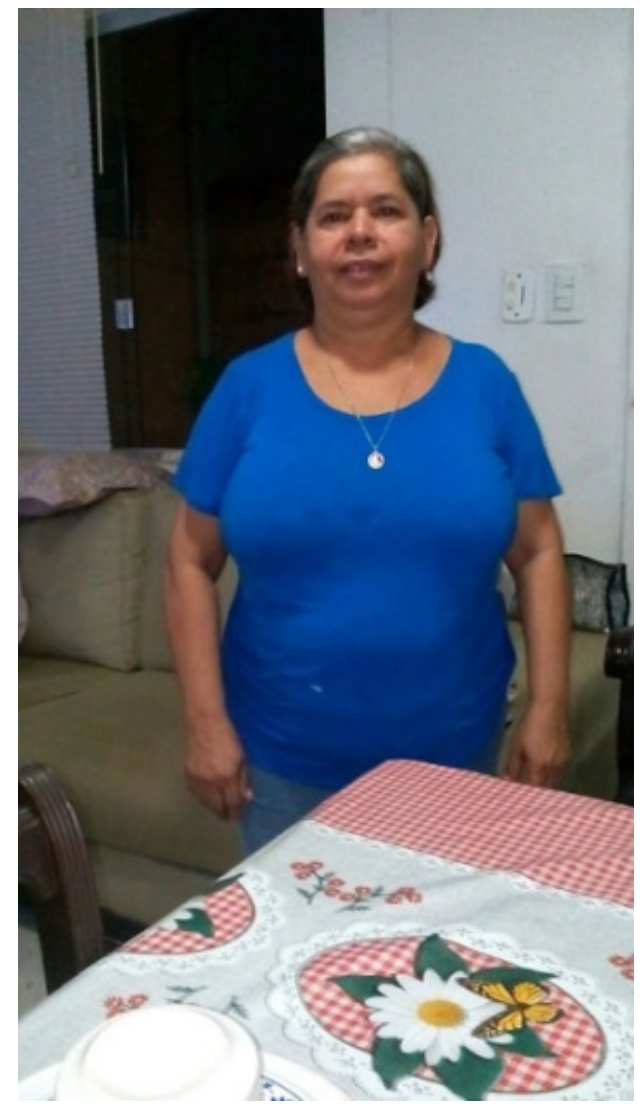


Radicalizando o Imaginário: Impactos das transformações do trabalho...
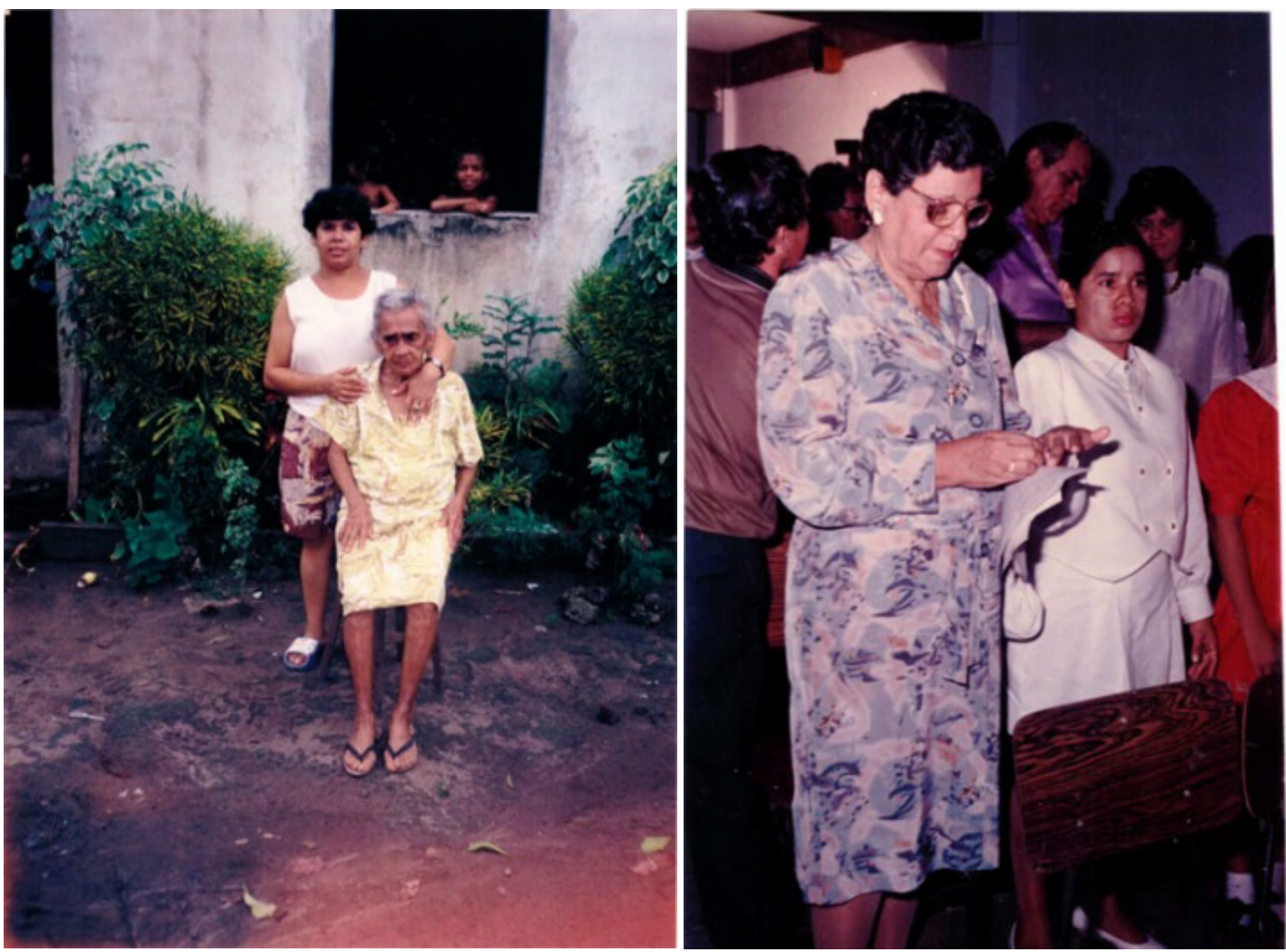

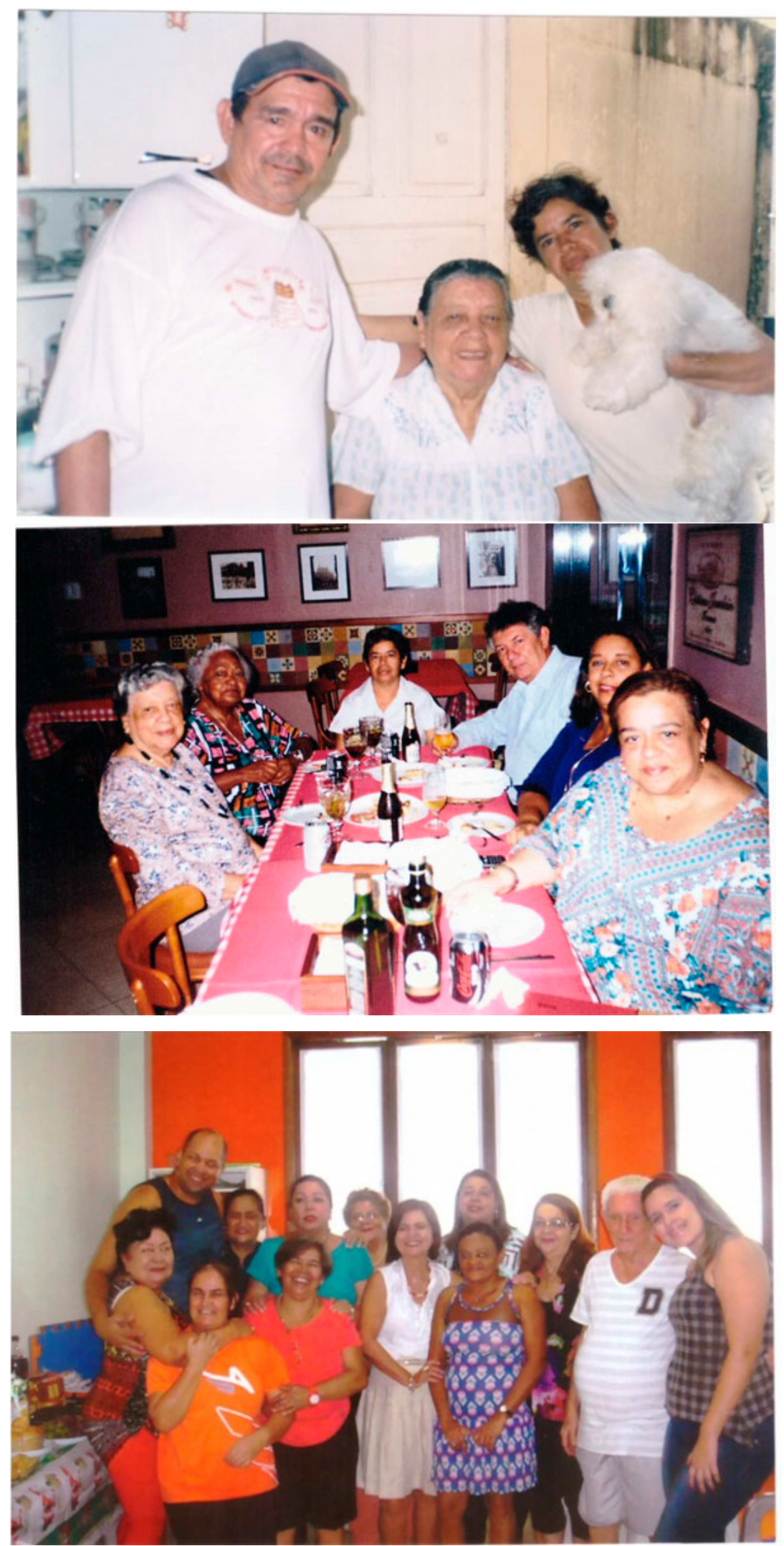

Figura 17: Fotografias da trajetória de Hilda selecionadas por ela. 
Radicalizando o Imaginário: Impactos das transformações do trabalho...
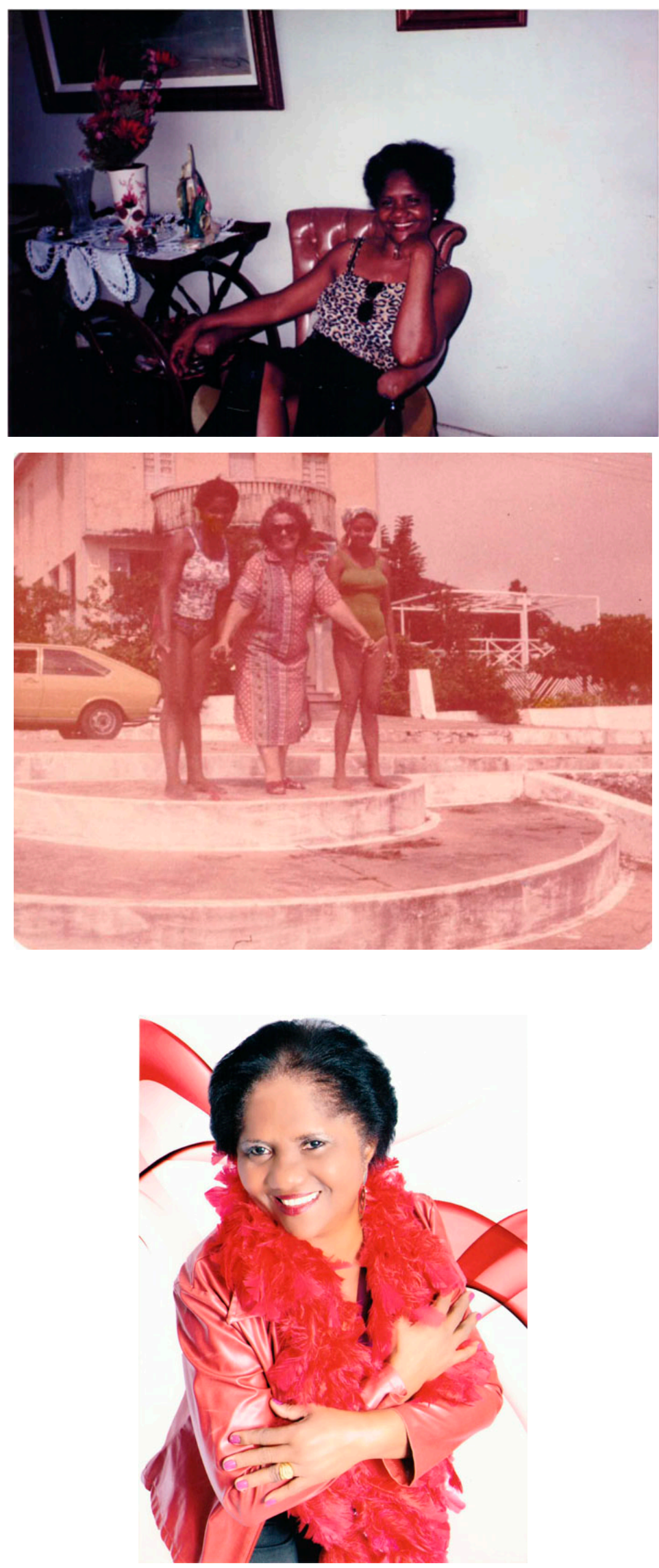
Já em Porto Alegre, a pesquisa foi realizada com maior densidade no sindicato das trabalhadoras e a produção de imagens, que ao início eu avaliei que não seria bem-vinda por tratar-se de um local de tensões e conflitos, contrariamente, mostrou-se como mecanismo de aproximação com as lideranças sindicais, que começaram a requerer que eu registrasse os momentos importantes, por exemplo quando a presidenta Salete foi homenageada e também durante a realização das entrevistas. $\mathrm{O}$ momento final de produção de imagens foi bastante esperado e em que a posição e local da fotografia, seja ela na presença de quadros ou com o auxílio de documentos que remetessem ao sindicato e o trabalho como um local de efetivação da justiça se fizeram bastante presentes, como no caso de Salete e Rosanne. Mais uma vez, abordamos uma dimensão do trabalho doméstico remunerado, em que a imagem relativa à doméstica uniformizada e trabalhando se mostrou bastante díspar. As trabalhadoras que não conheci por meio do sindicato preferiram que nossos encontros fossem em minha casa, então também não as interpelei em seus locais de trabalho e durante as suas jornadas.

Figura18: Salete, Fotos de 2013 - Autoria da pesquisadora ${ }^{40}$
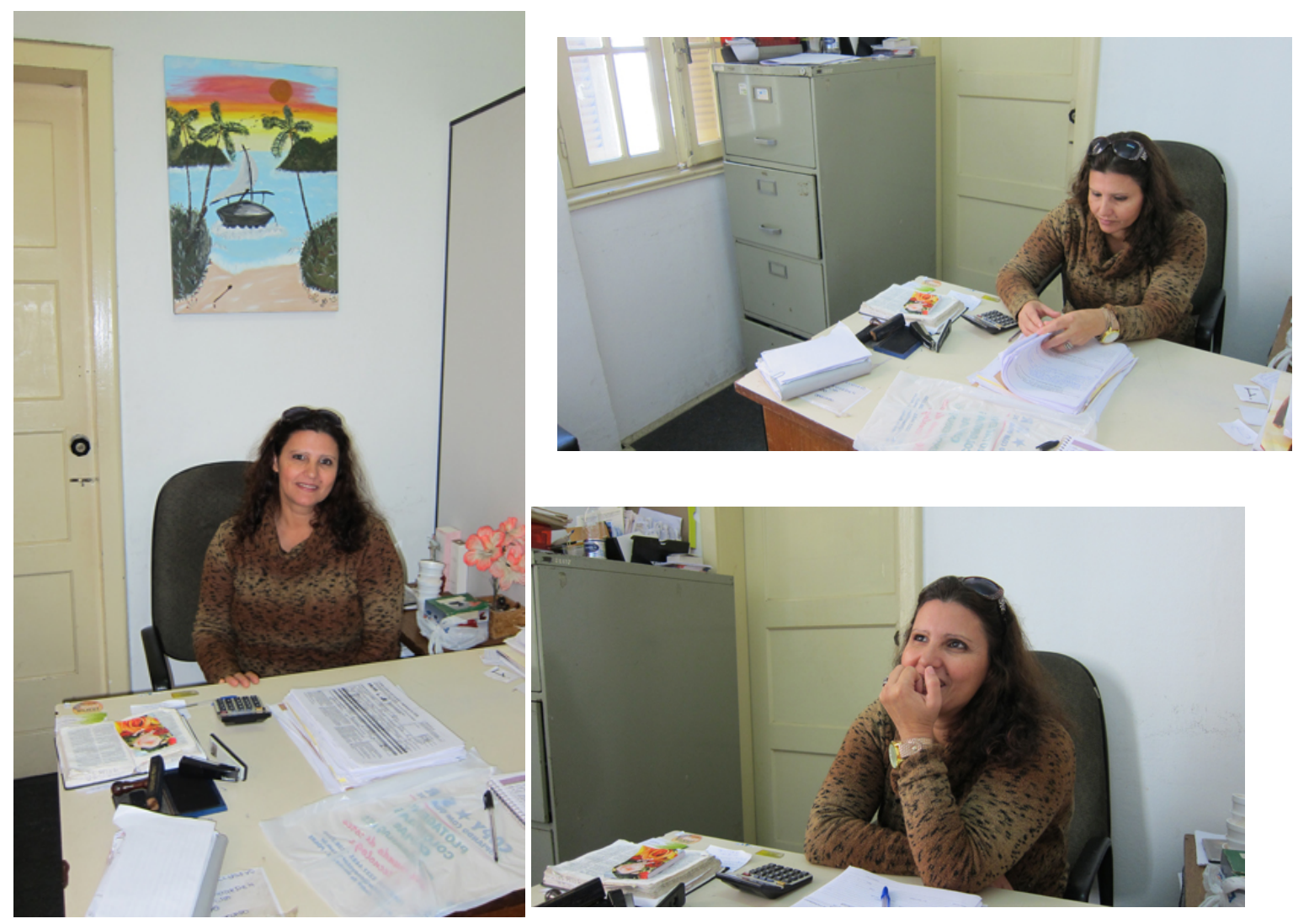

\footnotetext{
${ }^{40}$ Quadro pintado por Salete, que ela mostra com muito orgulho, juntamente a outros expostos na sua sala.
} 
Figura 19: Rosanne, Maria Regina e Salete, Fotos de 2013 - Autoria da pesquisadora

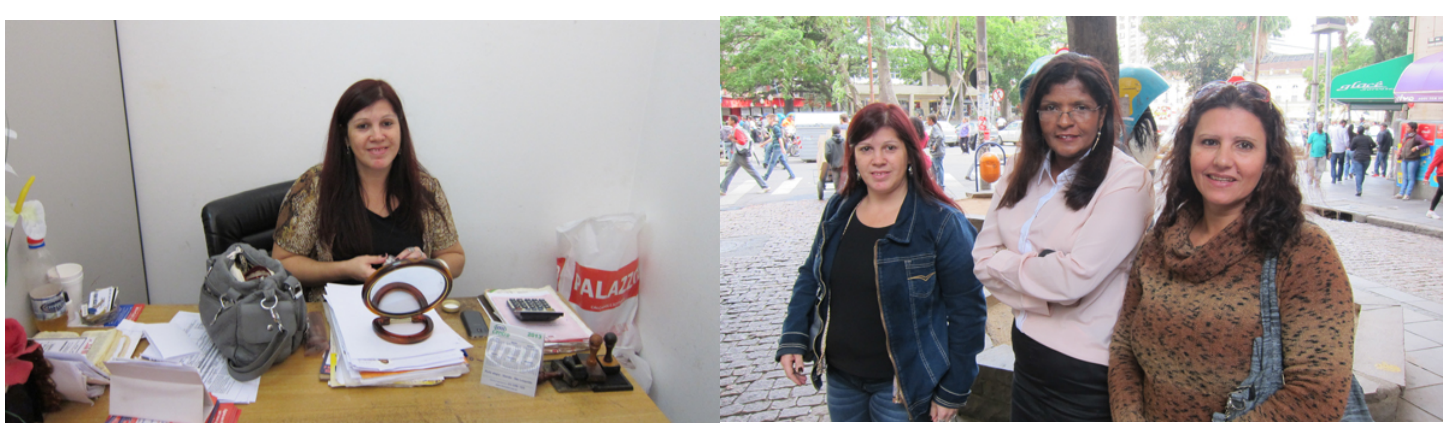

Figura 20: Homenagem à Salete, Fotos de 2013 - Autoria da pesquisadora

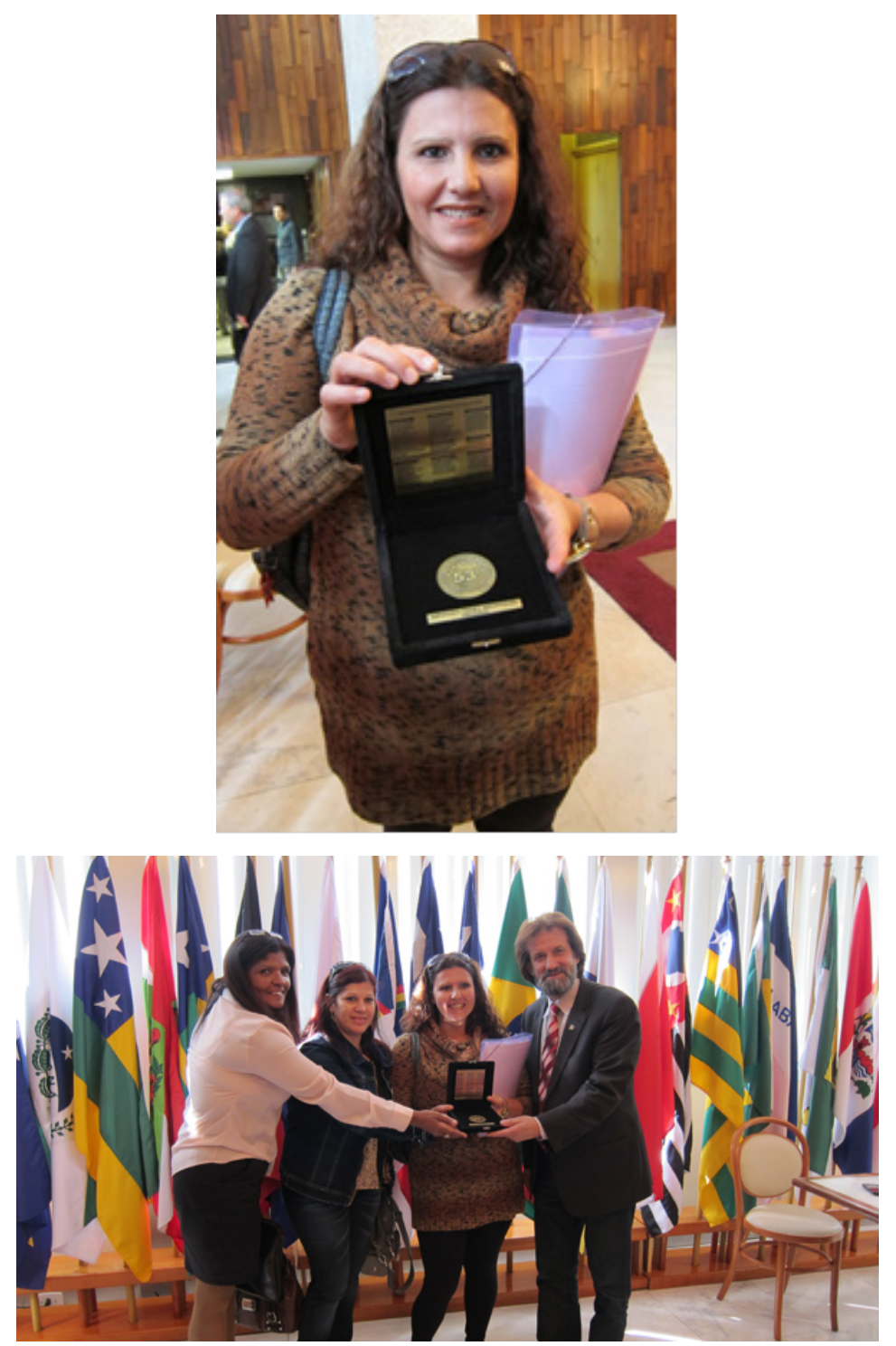


Figura 21: Marina, Fotos de 2013 - Autoria da pesquisadora.
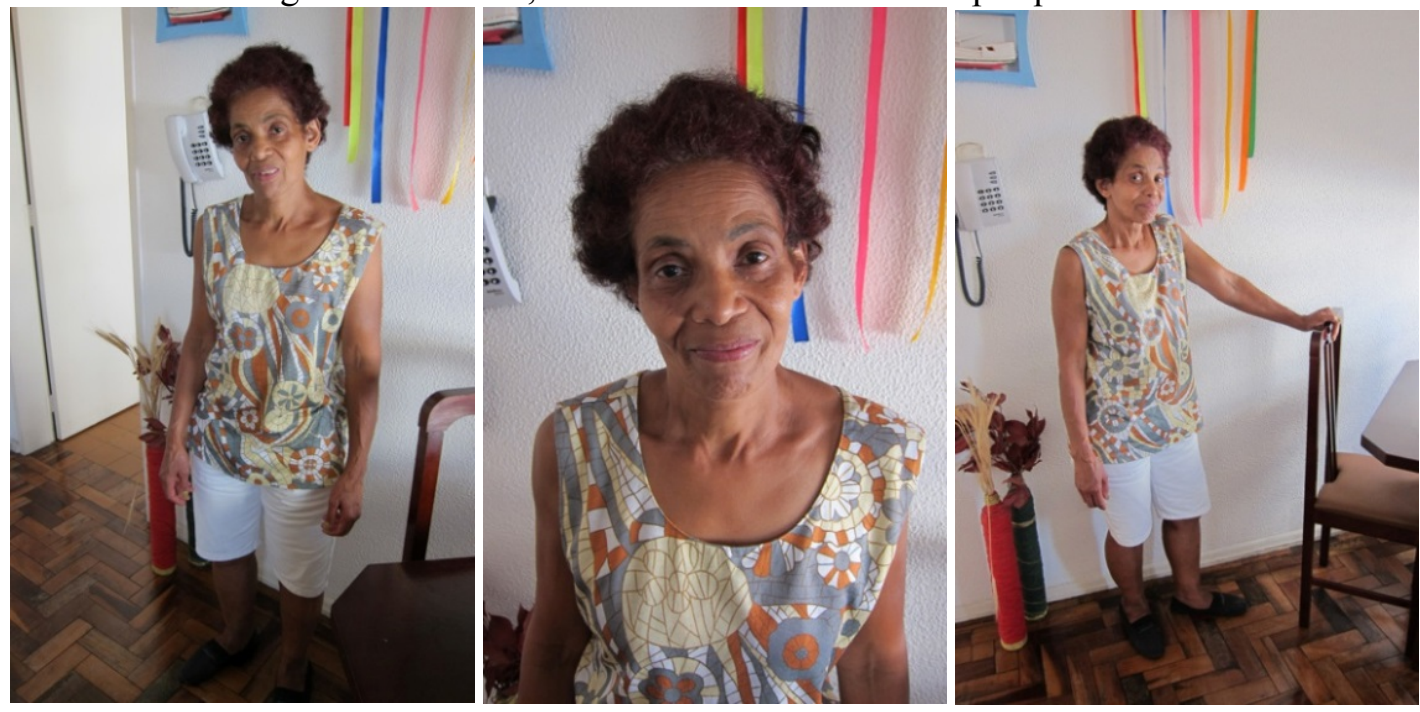

Figura 22: Patrícia em seu quarto, Fotos de 2013 - Autoria da pesquisadora
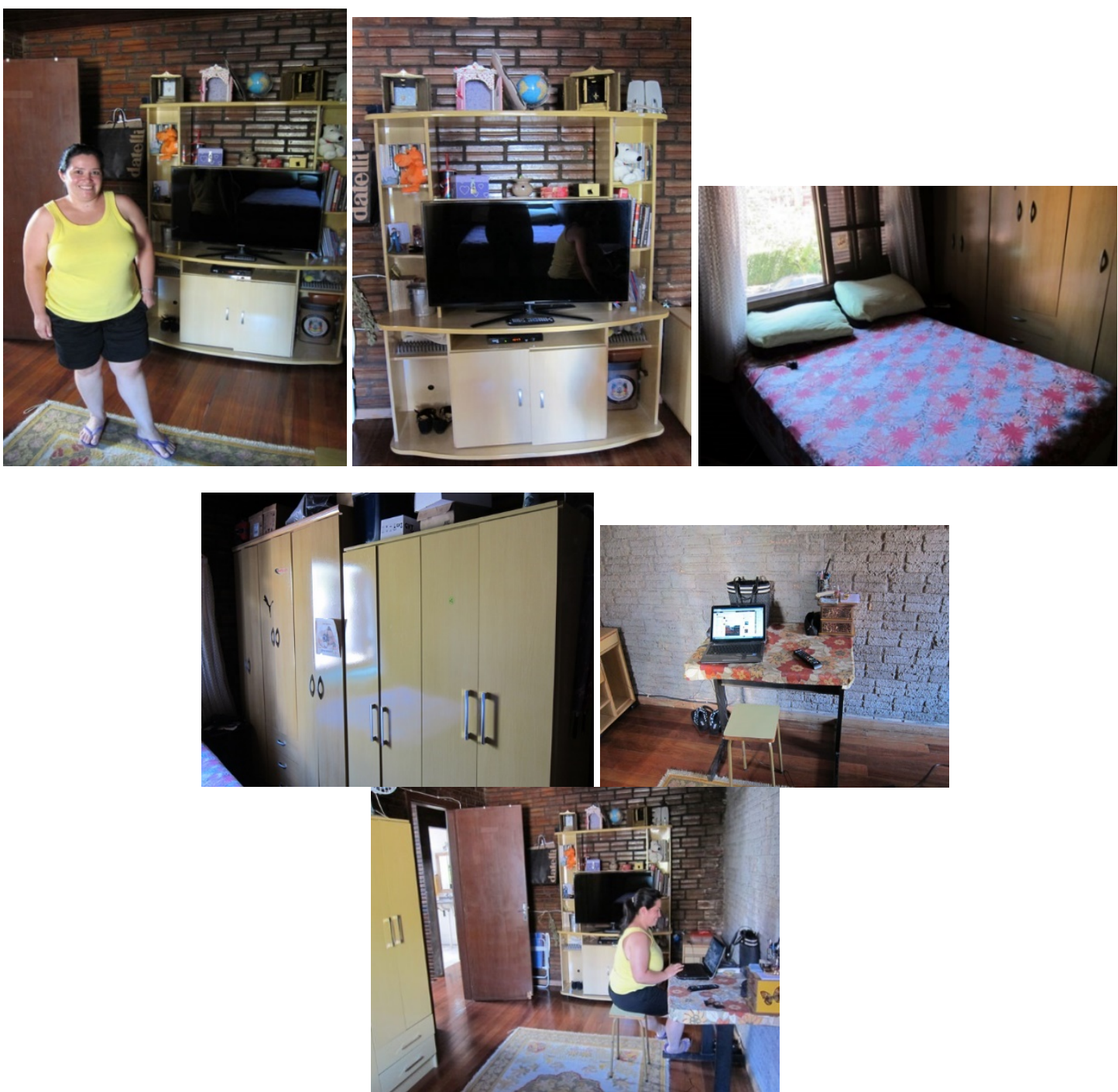
Radicalizando o Imaginário: Impactos das transformações do trabalho...
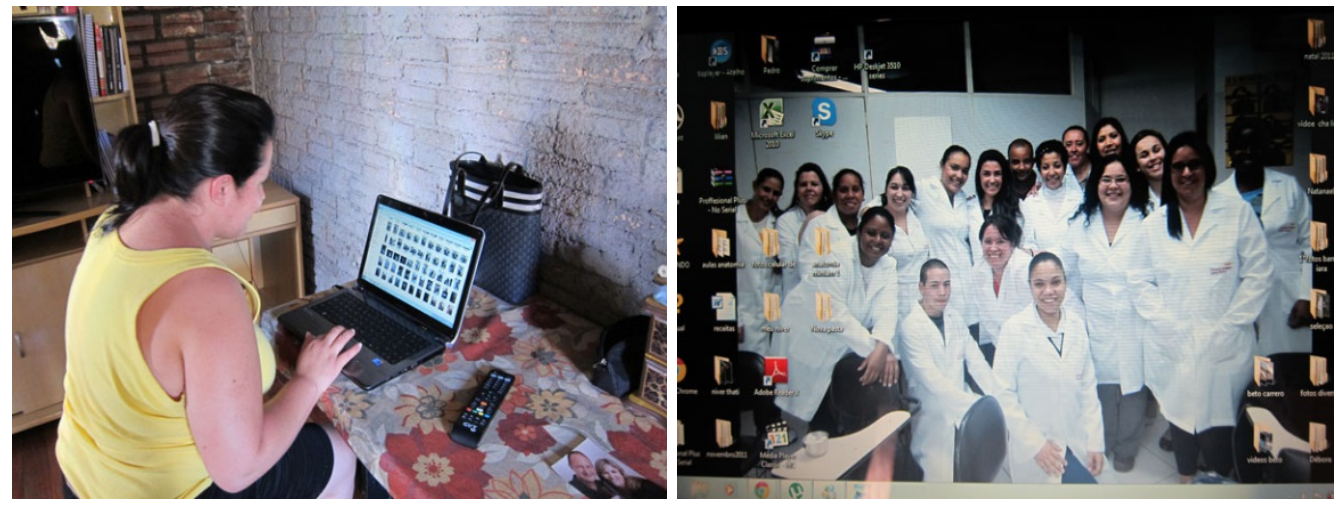

Figura 23: Telma, Fotos de 2013 - Autoria da pesquisadora.
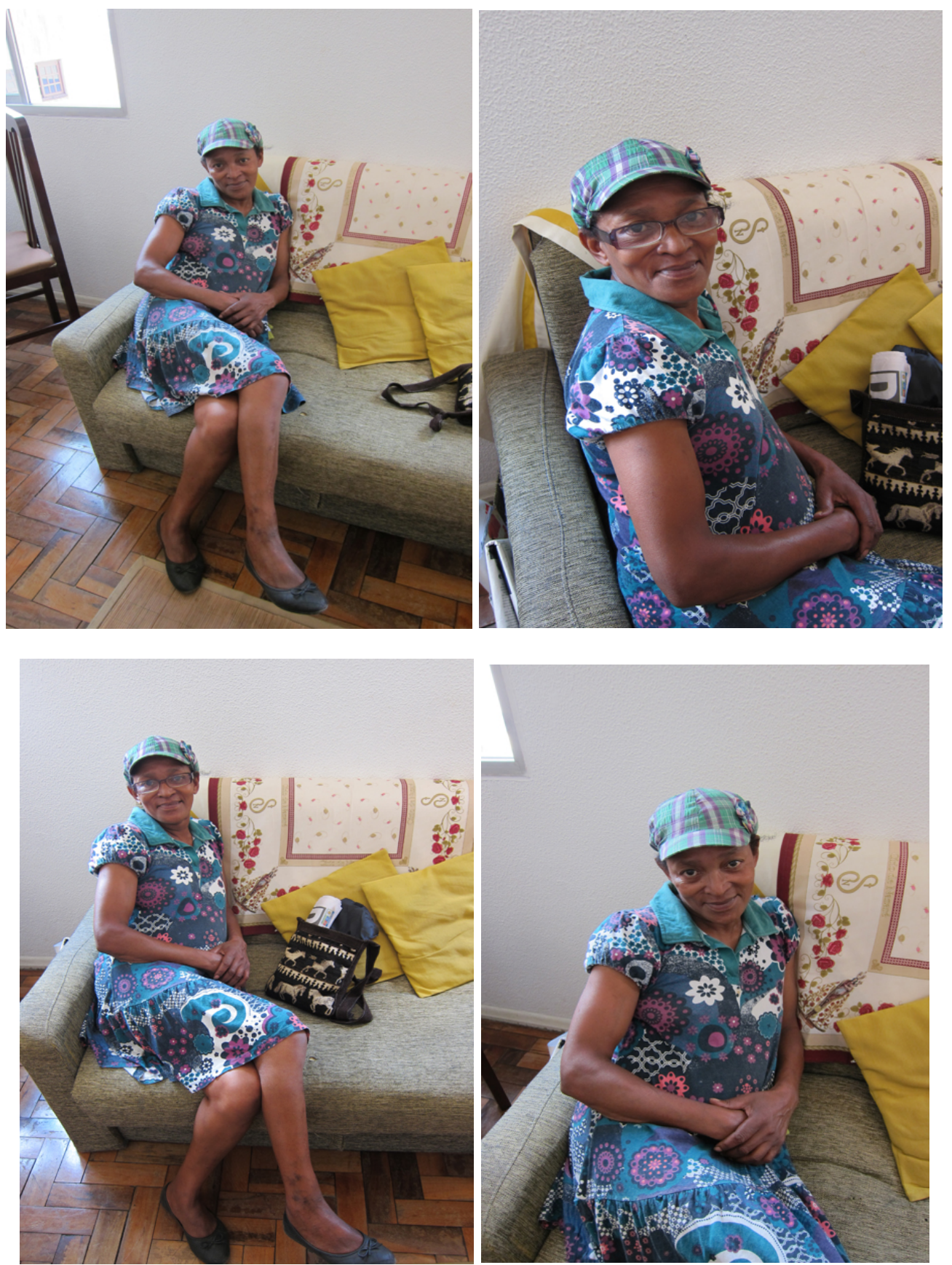
Em Salvador, as trabalhadoras domésticas se colocaram na posição de guias da cidade, então nossas imagens seguem minha introdução enquanto neófita naquele contexto urbano, participando dos itinerários, permeados por eventos políticos, religiosos e culturais em que minhas interlocutoras foram protagonistas. Da rua, adentrei ao espaço da casa e também do sindicato. Como em Porto Alegre, apenas com exceção de Belém, o espaço da casa dos patrões me foi negado. Mas também não insisti para que isso acontecesse, pois como uma opção metodológica achei por bem seguir minhas interlocutoras nos lugares em que quiseram me levar e nas imagens que elas quiseram construir de si e dos seus cotidianos.

Figura 1: Feijoada Sindoméstico/BA, Fotos de 2013 - Autoria da pesquisadora
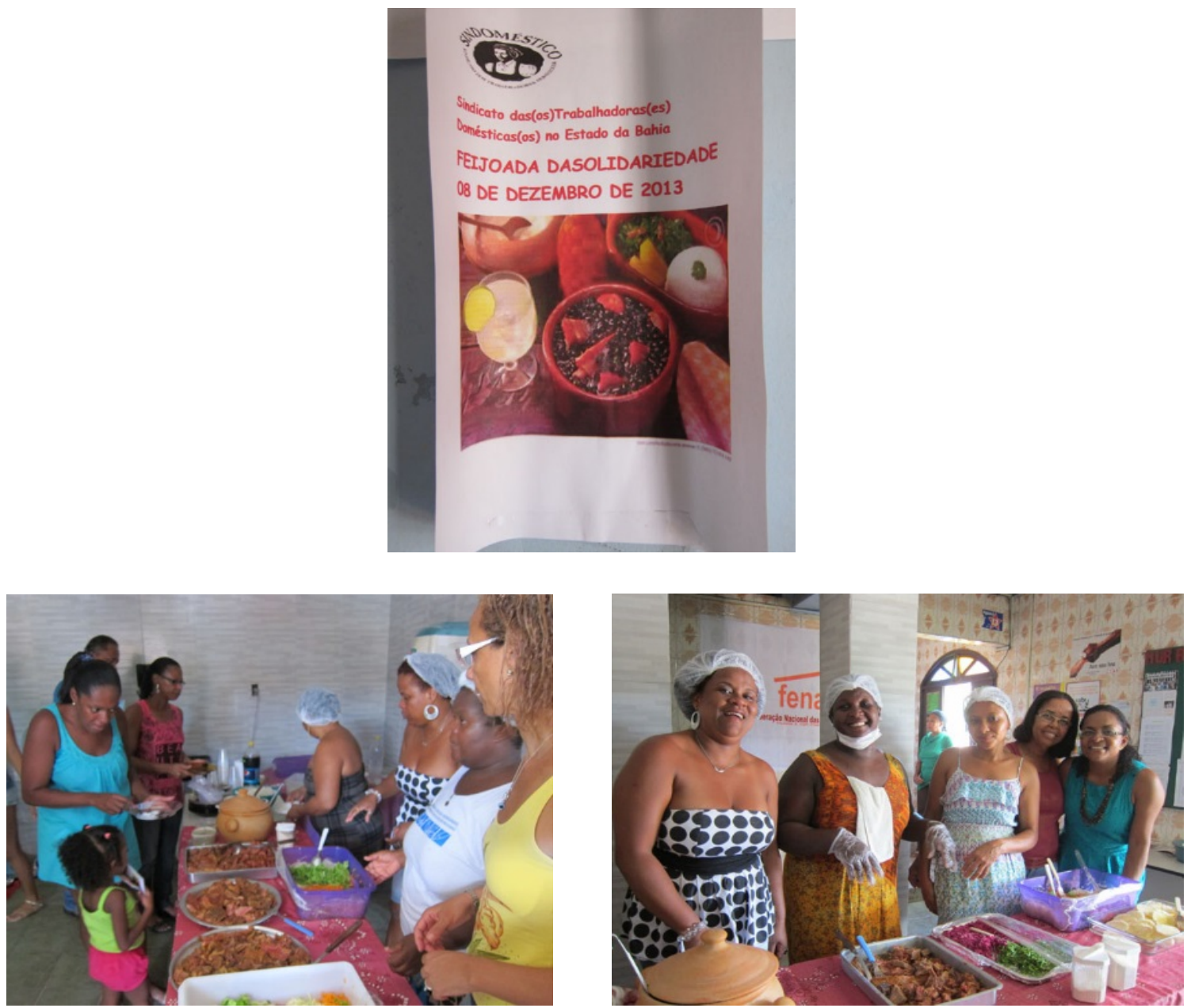
Radicalizando o Imaginário: Impactos das transformações do trabalho...

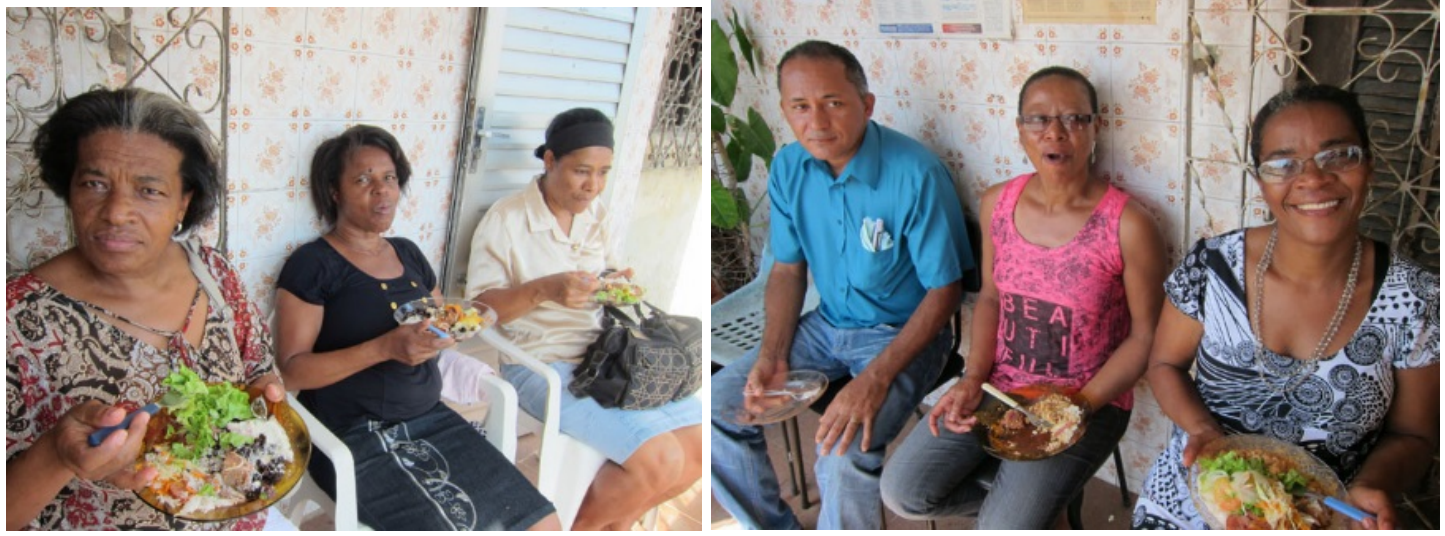

Figura 25: Audiência Pública, Fotos de 2013 - Autoria da pesquisadora
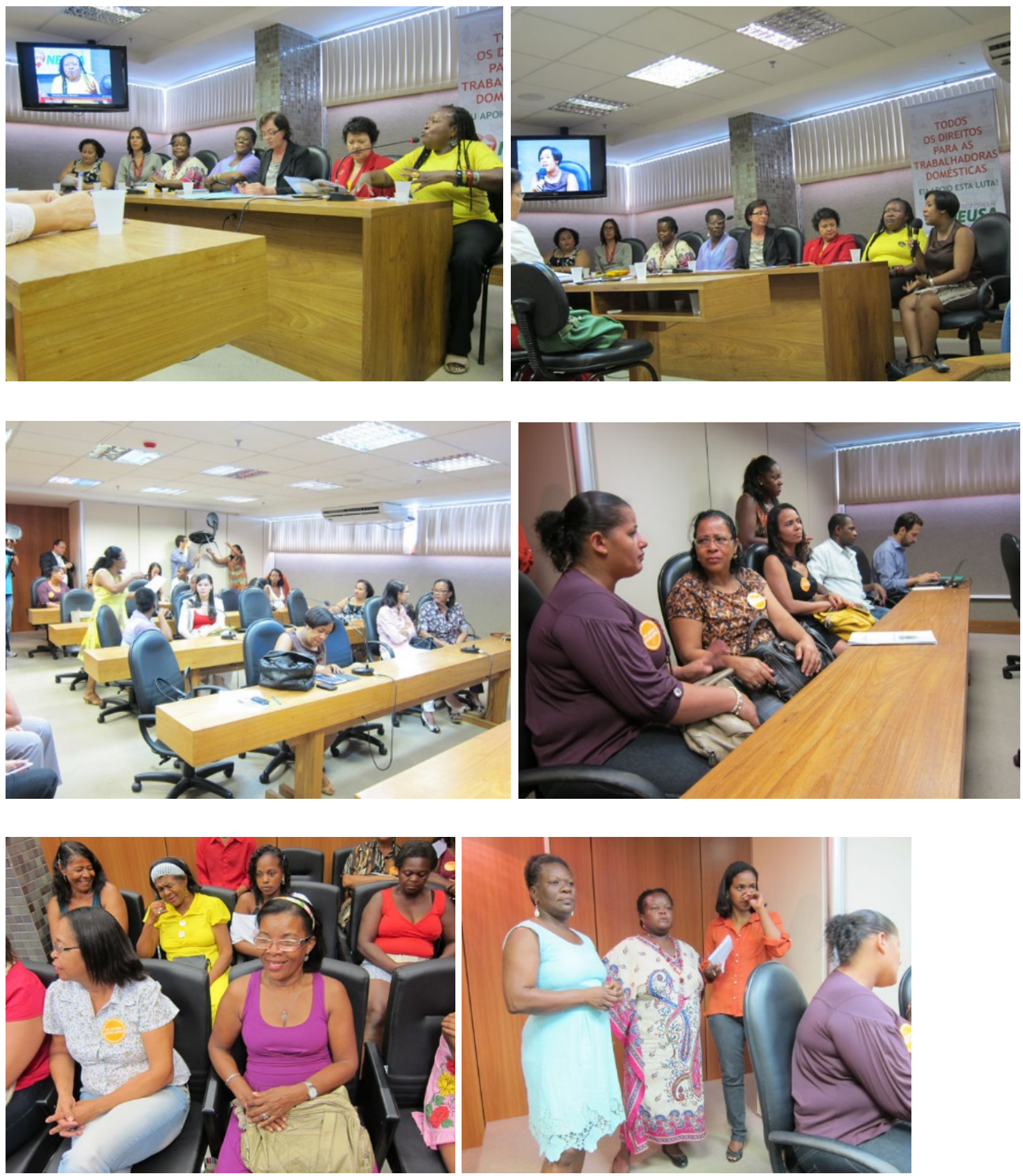
Figura 26: Balbina e Leninha no hall e casas de Tina e Leninha, Fotos de 2013 - Autoria da pesquisadora
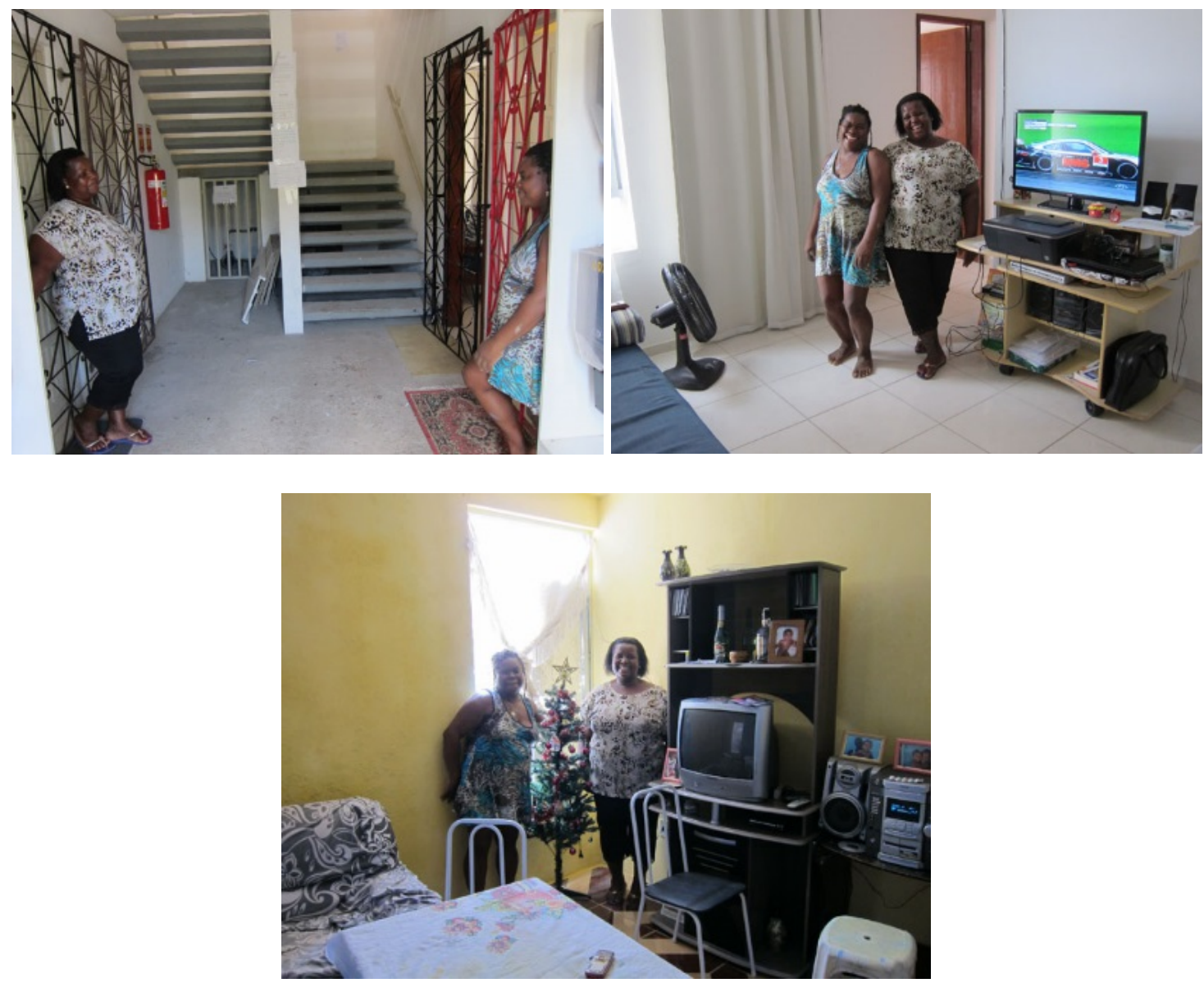

Figura 27: Cartografia da casa de Zezinha - Apto 201 - Prédio II - Maria das Graças

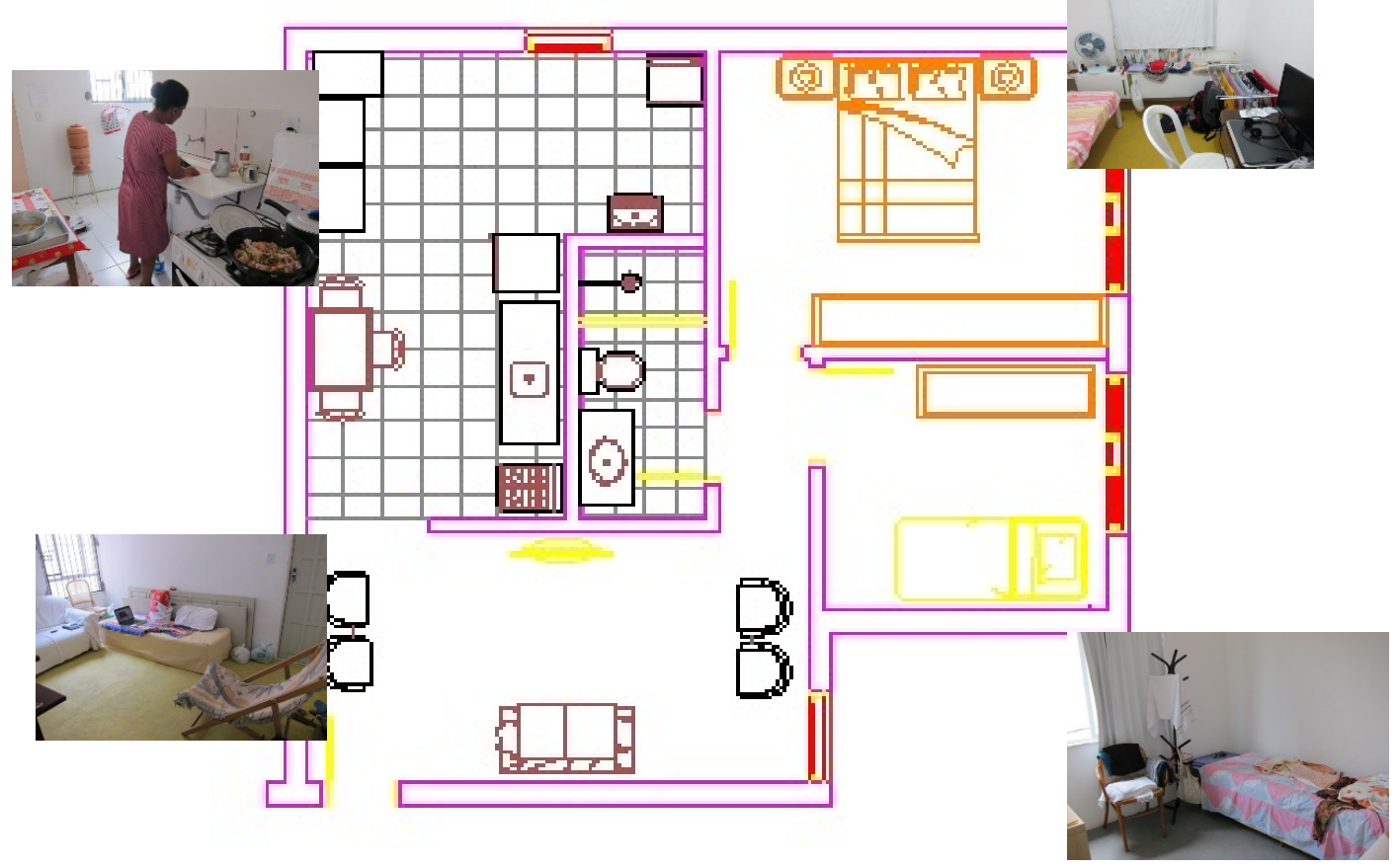


Radicalizando o Imaginário: Impactos das transformações do trabalho...

Apesar da mobilidade das imagens que as domésticas com quem aprendi e convivi quiseram construir de si no presente se distanciar bastante da imagem corrente apresentada nas diferentes mídias em relação a trabalhadoras domésticas, em suas narrativas biográficas o tempo relativo à infância, a adolescência e as experiências de trabalho convergem com as imagens de exploração, dominação, abuso e racismo presentes nos romances e pesquisas sobre o tema. Apenas o presente, talvez bastante influenciado pelas novas conquistas trabalhistas que produzem novas perspectivas para o grupo, ou ainda a aquisição da casa própria e a ocupação de espaços que antes lhes eram negados ou não almejados, como cargos políticos ou a intervenção em universidades e órgãos governamentais, parece estar modificando de forma enfática a imobilidade das formas do emprego doméstico, juntamente à emergência de subjetividades agenciadoras de novas e melhores condições de vida e trabalho (Ortner, 2007).

O filme Que horas ela volta? (2015) teve um grande impacto nesta conjuntura de modificações jurídicas, além dos efeitos de um governo que ampliou o acesso ao ensino superior, proporcionando às novas gerações de mulheres pobres, trabalhadoras e/ou filhas de domésticas o acesso às universidades, o que dantes não era imaginado e projetado pela maioria de minhas interlocutoras. Neste ponto o marcador geracional parece ser o ponto de mutação para as mudanças esperadas e que apenas poderão ser melhor visualizadas no decorrer dos próximos anos.

A realização de uma etnografia multi-situada (Marcus, 1995) tem o intuito de nos proporcionar uma mobilidade de imagens em diferentes campos, já que o que efetivamente nos desloca é o Outro; também diferentes posições e lugares de enunciação, para a experimentação de novas perspectivas e ângulos em relação ao mesmo fenômeno.

De forma resumida, podemos relatar que o percurso de nossa pesquisa inicia na casa dos patrões e o encontro com trabalhadoras, posteriormente busca os sindicatos das trabalhadoras, para então acessarmos seus espaços domésticos e de sociabilidade. Cada etapa da pesquisa de campo foi acompanhada por novas perguntas e questões teóricas suscitadas pelo campo e por novas leituras, buscando entender o que acontece nas dinâmicas internas que não é visto publicamente, ou a partir de um olhar inicial. 


\section{REFERÊNCIAS}

BACHELARD, Gastón. A dialética da duração. São Paulo: Ática, 1988.

BERGSON, Henri. Essai sur les donnés immédiates de la conscience. Paris: PUF, 1970.

BRASIL. Presidência da República. Casa Civil. Subchefia para Assuntos Jurídicos. Lei Complementar $n^{\circ} 150$, de $1^{\circ}$ de junho de 2015. Dispõe sobre o contrato de trabalho doméstico. Disponível em: http://www.planalto.gov.br/ccivil_03/leis/lcp/lcp150.htm. Acesso em: 6 de maio de 2017.

BRASIL, OIT. Convenção 182. 1999.

BRASIL, OIT. Convenção 189. 2011.

CHANEY, Elsa M; CASTRO, Mary G. (Orgs). Muchacha, Cachifa, Criada, Empleada, Empregadinha, Sirvienta y ... Màs Nada. Trabajadoras del Hogar en America Latina. 1 ed. Caracas - Venezuela: Editorial Nueva Sociedad, 1993.

CECÍLIA, Maria. Uma casa chamada 14. Belém: IAP, 2003.

DE ASSIS, Machado. Casa velha. Rio de Janeiro: 7Letras, 2004.

DE QUEIRÓS, Eça. O primo Basílio. São Paulo: NBL Editora, 1980.

DURAND, Gilbert. Science de l'homme et tradition. Paris: Berg International Editeurs, 1979.

Fontes, 2001.

As Estruturas Antropológicas do Imaginário. São Paulo, Martins

DEVETTER, François-Xavier, ROUSSEAU, Sandrine. Working time and sustanable consumption. Review of social economy (À paraître), 2011.

ECKERT, Cornelia; ROCHA, Ana Luiza C. Etnografia da duração: antropologia das memórias coletivas em coleções etnográficas. Porto Alegre: Marcavisual, 2013.

FRAGA, Alexandre B. De empregada a Diarista. As Novas Configurações do Trabalho Doméstico Remunerado. Rio de Janeiro: Editora Multifoco, 2013, 206 p.

GOLDSMITH, Mary. La experiência de Conlactraho como organización internacional de trabajadores y trabajadoras domésticas. Revista de derechos humanos - dfensor. Cidade do México, Número 01 - Enero 2012.

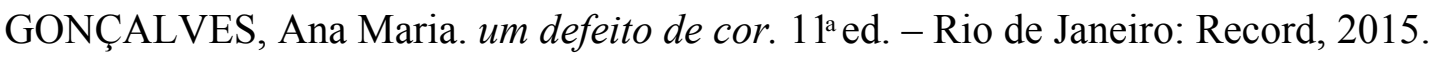

HALBWACHS, Maurice. A memória coletiva. São Paulo: Vértice, 1990. 
HATOUM, Milton. Dois irmãos. Editora Companhia das Letras, 2006.

JURANDIR, Dalcídio. Belém do Grão-Pará. São Paulo: Livraria Martins Editora, 1960. MARCUS, George. Ethnography in /of the world system. The Emergence of MultiSited Ethnography. In: Annual Review of Anthropology, n 24, p. 95-117, 1995.

RICOEUR, Paul. O si-mesmo como um outro. Trad. Luci Moreira Cesar. Campinas: Papirus, 1991. Tempo e Narrativa. São Paulo: Papirus, vols I, II, III, 1994.

ROSENBLATT, Sultana L. Barracão. Rio de Janeiro: Leitura, 1963.

SPIVAK, Gayatri C. Pode o subalterno falar? Belo Horizonte: Ed. UFMG, 2010.

UMRIGAR, Thrity. A Distância Entre Nós. São Paulo: Nova Fronteira, 2006.

VELHO, Gilberto. Individualismo e cultura. Rio de Janeiro, Zahar, 1981.

Recebido 04/03/2020

Aprovado 10/04/2020 